\title{
Recovering (From) Enlightenment?
}

STEVEN D. SMITH*

TABLE OF CONTENTS

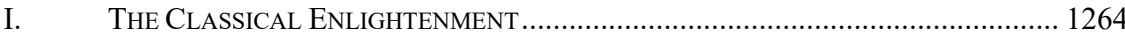

II. THE MODERN IDEAL: INVERTING THE ENLIGHTENMENT .................................. 1278

III. RENEWING THE ENLIGHTENMENT? ……........................................................ 1307

When we speak of the "Enlightenment," those of us who are not Buddhists commonly refer to a complex movement of thought, culture, temperament, and politics represented in its early phases by thinkers like Descartes and Locke, and in its later phases by figures like Kant or, in America, Jefferson and Paine. This self-styled "Age of Reason," or what we might call the "historical" or "classical" Enlightenment, is often said to have succumbed in the nineteenth century to the forces of reaction and romanticism. But the Enlightenment is also invoked, most often by or on behalf of modern liberal political and constitutional theorists, ${ }^{1}$ to designate a sort of political-moral ideal that ostensibly has

* Warren Distinguished Professor of Law, University of San Diego. I thank Larry Alexander, Curt Bradley, Rick Garnett, Vittorio Hosle, Andy Koppleman, Bob Nagel, Michael Perry, Stephen Presser, George Rutherglen, Philip Quinn, George Wright, and Michael Zuckert for helpful comments on earlier drafts. A slightly different version of this Article was presented at a conference on "America and the Enlightenment: Constitutionalism in the $21^{\text {st }}$ Century" in November 2001 in London, sponsored by the Institute of United States Studies, University of London.

1. Indeed, liberalism and Enlightenment are sometimes conflated. See, e.g., Bruce A. Ackerman, Law, Economics, and the Problem of Legal Culture, 1986 DUKE 
guided and continues to guide American constitutionalism. This more modern iteration is supposed to be connected to the historical Enlightenment, it seems, mainly on the basis of a professed allegiance to governance by "reason."

In this essay I will argue that although there are indeed continuities between the classical Enlightenment and "the spirit of the Enlightenment" 2 that animates contemporary thinkers, these continuities are partly cosmetic and in any case are overwhelmed by the discrepancies. The modern Enlightenment orientation reflected in liberal political and constitutional theorizing is more accurately understood as an inversion than as an extension of the most essential ideals of the Enlightenment commitments to liberty, equality, freedom of conscience, and freedom of speech-commitments that today are endlessly elaborated but largely undefended and that consequently seem fragile. So those who would maintain these historic commitments might naturally wish for a recovery of the ideals and assumptions of the classical Enlightenment. And the formidable (and for the moment, I fear, insuperable) obstacle to any such recovery is... the modern Enlightenment.

\section{THE CLASSICAL ENLIGHTENMENT}

The historical Enlightenment was, as Roy Porter notes, "necessarily rather amorphous and diverse," 3 and any brief (or, for that matter, long) description of it will thus reflect a selective interpretation. With that caveat, I suggest that for present purposes the classical Enlightenment can be understood in terms of several components that were, in the seventeenth and eighteenth centuries, nicely harmonious.

The commitment to truth. In his Discourse on Method, Descartes reports that he had "always had an especially great desire to learn to distinguish the true from the false."4 And he immediately explains the practical thrust of this desire: he wanted truth, he says, "in order to see my way clearly in my actions, and to go forward with confidence in this

L.J. 929, 937 (1986) (referring to "the Liberal Enlightenment faith founded by Adam Smith and James Madison"). And thinkers tending to the "liberal center" seem more inclined to invoke the Enlightenment than do those either to the left or the right of that position. See, e.g., Suzanna Sherry, The Sleep of Reason, 84 GEO. L.J. 453, 453 (1996) (associating the Constitution with Enlightenment reason, and arguing that this centrist position is under attack from both "the left and the right").

2. BRUCE ACKerman, We the PeOPle: Foundations 159-60 (1991).

3. ROY PORTER, THE ENLightenMENT 9 (2d ed. 2001).

4. Rene Descartes, Discourse On Method and Meditations on First

Philosophy 6 (Donald A. Cress trans., Hackett Publ'g. Co. 4th ed. 1998). 
life." Descartes's report captures an essential impulse that drove the Enlightenment: a compulsion both to know truth and to live by it. Vocabulary varied, to be sure. Terms like "reason" and the "life of reason" incorporated this imperative. ${ }^{6}$ And instead of the diction of living according to "truth," the classical Enlightenment often favored the vocabulary of living in accordance with "nature," - as in the Declaration of Independence's invocation of "nature and nature's God." 8 The idea was not novel, of course - "You shall know the truth, and the truth shall make you free" had been said before-but it was nonetheless fundamental to the project of the classical Enlightenment.

Reason, nature, and truth were guiding precepts for the framers of the American Constitution, or so they declared; their intention was to build a new constitutional order on the basis of the truths of human nature and the best political science, which they saw as revealing truths about government that had previously been obscure. ${ }^{9}$ Tocqueville noticed this aspect of the founding: in an encomium to the framers of the Constitution, he emphasized that "[t]hey had the courage to say what they believed to be true ...."10 Moreover, in this respect, the framers were following the example of the signatories of the Declaration of Independence - a document that explicitly manifested the commitment to living by truth. In declaring their intention to engage in a bloody conflict to break political bonds established over centuries, the American founders had insisted that they were acting not merely from self-interest, but rather on the basis of fundamental and self-evident truths; and in

5. Id.

6. In this vein, Nicholas Wolterstorff notes that according to Locke, "to be human is to have Reason speaking within one. It is this that sets us off from the 'brutes'...." Reason, in Locke's understanding, is an epistemic faculty, but it is much more than that: it is an ethical ideal. "Reason is to be our guide." NiCHOLAS WOLTERSTORFF, JOHN LOCKE AND THE ETHICS OF BELIEF 86-87 (1996).

7. See Carl L. Becker, The Heavenly City of the Eighteenth-Century PHILOSOPHERS 47-51 (1932); see id. at 51 ("Nature and natural law-what magic these words held for the philosophical century!").

8. THE DECLARATION OF INDEPENDENCE para. 1 (U.S. 1776).

9. See, e.g., The Federalist No. 9 (Alexander Hamilton); $c f$. Fullilove v. Klutznick, 448 U.S. 448, 531 n.13 (1980) (Stewart, J., dissenting) (describing the "Framers of our Constitution" as "products of the Age of Enlightenment"). For a more extensive discussion of how the framers saw the Constitution as an unprecedented manifestation of reason, see Steven D. SMith, THe Constitution \& THE PRide of REASON 3-4, 31-47 (1998) [hereinafter SMITH, REASON].

10. Quoted in Henry F. MAY, The Divided Heart: Essays on Protestantism AND THE ENLIGHTENMENT IN AMERICA 159 (1991) [hereinafter MAY, DividED HEART]. 
what was more than a dramatic gesture ${ }^{11}$ they had staked on those truths their "lives," their "fortunes," and their "sacred honor."

Lincoln called attention to this truth-oriented dimension of the founding when he observed, in the Gettysburg Address, that the American republic was founded on a "proposition." 12 Almost a century later, John Courtney Murray eloquently made the point: what he called the "American Proposition"

rests on the ... conviction that there are truths; that they can be known; that they must be held; for, if they are not held, assented to, consented to, worked into the texture of institutions, there can be no hope of founding a true City, in which men may dwell in dignity, peace, unity, justice, well-being, freedom.13

A commitment to living in accordance with truth presupposes, of course, that there is in fact a truth of the sort that prescribes how to live, and how to live together-hence, a moral and political truth. Modern thinkers occasionally distinguish this sort of overarching truth from the mundane facts or merely pragmatic propositions that pervade everyday life by capitalizing the word (often with a derisive tone). ${ }^{14}$ So we could say that at the heart of the classical Enlightenment was a belief in, and a resolve to live by, the Truth.

Reason versus culture. The commitment to living by the Truth entailed, for the Enlightenment, the exercise of reason; and reason in turn implied an effort to break free of the impediments and errors of culture and tradition. ${ }^{15}$ Indeed, reliance on received opinions embodied in culture was taken to be the opposite of reason; the whole point of reason was to free persons from the moral and epistemic corruption that

11. $C f$. Joseph J. ElLis, Founding Brothers 5 (2000):

Based on what we now know about the military history of the American Revolution, if the British commanders had prosecuted the war more vigorously in its earliest stages, the Continental Army might very well have been destroyed at the start and the movement for American independence nipped in the bud. The signers of the Declaration would then have been hunted down, tried, and executed for treason .... .

12. Abraham Lincoln, The Gettysburg Address (Nov. 19, 1863), in CARL F. WIECK, LINCOLN'S QUEST FOR EQUALITY 145-46 (2002).

13. John Courtney Murray, S.J., We Hold These Truths: Catholic REFLECTIONS ON THE AMERICAN PROPOSITION ix (1960).

14. See, e.g., Ackerman, supra note 1, at 937 (describing people who believe they have discovered "the Truth about Jesus"). Richard Rorty explains that "[u]ncapitalized, 'truth' and 'goodness' name properties of sentences, or of actions and situations. Capitalized, they are the proper names of objects - goals or standards which can be loved with all one's heart and soul and mind, objects of ultimate concern." RICHARD RORTY, CONSEQUENCES OF PRAGMATISM xiv (1982).

15. Cf. Donald W. Livingston, The Founding and the Enlightenment: Two Theories of Sovereignty, in VITAL REMNANTS: AMERICA's FOUNDING AND THE WESTERN TRADITION 243, 244 (Gary L. Gregg II ed., 1999) ("[R]eason is conceived as being independent of tradition. Tradition is the great horror of the Enlightenment ...."). 
pervades culture and received tradition. Thus, Kant famously answered the question, "What is enlightenment?" by explaining that it means thinking for oneself, and that an "inability to make use of one's own understanding without the guidance of another" is a form of "immaturity" reflective of "[1]aziness and cowardice."16 The modern rationalist stance, Ernest Gellner explains, is "a programme for man's liberation from culture." 17

The seminal example, once again, was set by Descartes, for whom reasoning entailed a resolution to "get rid of [all received judgments and opinions] once and for all" in order to start from scratch in developing reliable knowledge. ${ }^{18}$ "[I]n truly rationalist spirit," Gellner observes, Descartes "decided to declare independence of the accidental assemblage of beliefs, of all cultural accretion, and to set out independently on a reexploration of the world." 19 Later Enlightenment thinkers drastically revised the details of the Cartesian program, but "the spirit of the inquiry and its implicit terms of reference remained much as Descartes had formulated them." 20 Thus, modern Enlightenment reason amounts to a "culture-defying individualism, a Robinson Crusoe posture." 21

From our perspective, to be sure, this setting of reason in opposition to culture might seem misguided. A theme running through twentiethcentury philosophy and associated with diverse thinkers such as Wittgenstein, Gadamer, and Rorty, holds that reason is inevitably embedded in culture, or "forms of life." We always and necessarily think and talk from within a language, an intellectual tradition, a

16. See generally Immanuel Kant, An Answer to the Question: What is Enlightenment?, reprinted in WHAT IS ENLIGHTENMENT? EIGHTEENTH-CENTURY ANSWERS AND TWENTIETH-CENTURY QuESTIONS 58 (James Schmidt ed., 1996).

17. ERnest Gellner, Reason and Culture 13 (1992).

18. See DESCARTES, supra note 4, at 8:

[A]s regards all the opinions to which I had until now given credence, I could not do better than to try to get rid of them once and for all, in order to replace them later on, either with other ones that are better, or even with the same ones once I had reconciled them to the norms of reason. And I firmly believed that by this means I would succeed in conducting my life much better than if I were to build only upon old foundations ....

19. GELLNER, supra note 17, at 18.

20. Id. at 13 .

21. Id. at 14; see also Stephen Toulmin, Cosmopolis: The Hidden Agenda of MODERNITY 175 (1990) ("[T]he idea of 'starting again with a clean slate' has been as recurrent a preoccupation of modern European thinkers as the quest for certainty itself. The belief [is] that any new construction is truly rational only if it demolishes all that was there before and starts from scratch ...."). 
"paradigm"- from within a culture. So the effort to detach reason from culture may seem akin to an attempt to separate speech from language or music from sound. ${ }^{22}$ Though a strong proponent of Enlightenment reason, Gellner admits as much: it was never possible, he says, to detach reason from culture, as Descartes and his successors wanted to do. So what actually resulted was simply a different kind of culture-a rationalist culture. ${ }^{23}$

The Enlightenment's apparent naivete on this point is accentuated, it may seem, by the embarrassing fact that Enlightenment thinkers came nowhere near agreement about exactly what reason is, or how it works. Empirically-minded thinkers such as Locke criticized the epistemology of rationalists such as Descartes and were in turn criticized by idealists like Berkeley and by more skeptical thinkers such as Hume. Gellner's study describes the large differences in what modern thinkers associated with or influenced by the Enlightenment have taken reason to be. Given this diversity, a cynic might be excused for concluding that the Enlightenment is defined by an exuberant common commitment to ... a word, nothing more.

So, was the Enlightenment the child of a rash misconception? Perhaps. There is no use denying that the luminaries of the Age of Reason were, as James Whitman observes, "fallible, and often comically fallible, human beings." 24 They may have been guilty of massive selfdeception, as Carl Becker's classic study wittily argued. ${ }^{25}$ Still, there is a more charitable interpretation that depicts the Enlightenment conception of reason in a more sympathetic way. We might understand the Cartesian distinction between reason and culture, that is, in less overtly philosophical and also less absolute terms. The determination to liberate reason from culture might be seen not as a misguided attempt to leave culture behind altogether, like a spaceship leaving the planet for the outer reaches of the cosmos, but rather as an effort to get beyond or behind particular aspects of a particular culture that are seen to be decadent, exhausted, or inauthentic.

Even this more modest sort of effort may still be misguided or unduly optimistic, of course, but it is one we can surely sympathize with, at least

22. Cf. Toulmin, supra note 21 , at 178 ("The belief that, by cutting ourselves off from the inherited ideas of our cultures, we can 'clean the slate' and make a fresh start, is as illusory as the hope for a comprehensive system of theory that is capable of giving us timeless certainty and coherence.").

23. "We are not free of culture, of Custom and Example: but it is of the essence of our culture that it is rooted in the rationalist aspirations." GELLNER, supra note 17, at 159.

24. James Q. Whitman, Reason or Hermeticism?: A Comment, 5 S. CAL. INTERDISC. L.J. 193, 195 (1997).

25. See BECKER, supra note 7. 
in the abstract. The phenomenon appears repeatedly throughout history. A culture or tradition or body of conventions comes to seem (to a few, perhaps not to most participants) empty, pointless, dead-little more than a burly corpse made up of inherited behaviors and rote questions and responses that can no longer elicit genuine belief or commitment. A form of discourse seems to be "just words." In this mood, Socrates ponders the moral discourse being practiced by his fellow Greeks and concludes that even though his neighbors seem satisfied with their ways of talking, for anyone who pays close attention, the discourse leads only to confusion, or aporia. His interlocutors are "playing with words but revealing nothing." 26 Or a loose group of self-styled "legal realists" considers the "formalist" arguments that their contemporaries are engaged in and finds it hard to fathom how anyone could suppose that this form of argumentation actually produces satisfactory answers to legal disputes. The standard law talk, it seems to the realists, "is in terms of words; it centers on words; it has the utmost difficulty in getting beyond words." ${ }^{27}$ Or, it is "transcendental nonsense." 28

In such situations, it is natural to try to escape the corrupt conventions or dissolute discourse and to discover or recover something more solidto find or return to "first principles." Thus, Jesus urges his followers to forsake artificial traditions in favor of the more fundamental injunctions to love God and neighbor. ${ }^{29}$ The Protestant reformers rebel against what they believe to be decadent Christian traditions in an effort to return to primitive Christianity; their own descendants repeatedly undertake the same quest. Emerson and Thoreau inveigh against tradition and convention and in favor of "nature" and a romantically conceived "reason." Legal realists and their successors deconstruct formalist legal reasoning and advocate its replacement by something they suppose to be more real and solid- "policy science," perhaps. The basic phenomenon is familiar enough: the disaffected come to believe that a particular culture or discourse has become empty or inauthentic, and they determine to find or return to something more solid.

More solid or, we might better say, more true: it is imperative to

26. Plato, Gorgias 489e, in The Collected Dialogues of Plato 272 (Edith Hamilton \& Huntington Cairns eds., 1961).

27. Karl N. Llewellyn, A Realistic Jurisprudence-The Next Step, 30 Colum. L. REV. 431, 443 (1930).

28. Felix Cohen, Transcendental Nonsense and the Functional Approach, 35 COLUM. L. REV. 809 (1935).

29. Mark 7:1-16, 12:28-34. 
remember that Enlightenment reason grows out of a commitment to live by the truth. At the core of the classical Enlightenment was a sense-whether it was correct we need not say-that the scholastic philosophy and religious culture inherited from the Middle Ages and the more unsettled intellectual culture of early modernity were not based on or oriented to truth. ${ }^{30}$ So eighteenth-century thinkers "made a great point of having renounced the superstition and hocus-pocus of medieval Christian thought." 31 And reason expressed their attempt to base their personal and collective lives on the truth-through more careful reflection, as with Descartes, or through the developing methods of science advocated by Bacon and practiced with notable success by Galileo and Newton.

Stephen Toulmin's interpretation elaborates on this suggestion. In the aftermath of the breakup of Christendom, Toulmin suggests, thinkers like Montaigne had developed a modestly skeptical orientation that was vaguely Christian and broadly humanistic. ${ }^{32}$ This late sixteenth-century intellectual style had exhibited a "readiness to live with uncertainty, ambiguity, and differences of opinion" and, yes, a certain amount of "higgledy-piggledy confusion." ${ }_{33}$ Toulmin himself finds this mindset alluring, and indeed urges a return to it. ${ }^{34}$ But he reports that seventeenth-century thinkers like Descartes found this complacent, moderately skeptical attitude unendurable. ${ }^{35}$ Their dissatisfaction expressed more than personal predilections: to people like Descartes or John Donne, the embrace of uncertainty and ambiguity seemed to be producing social chaos-“"Tis all in pieces, all cohaerance gone" ${ }^{36}$ - and despite its own easygoing tolerance, the sixteenth-century humanist stance appeared powerless to end the religious strife that seemed to be devouring Europe. ${ }^{37}$ In short, Europe was suffering from a "crisis of belief" 38 - a crisis with disastrous practical consequences. In this context, Descartes's "reflections opened up for people in his generation a real hope of reasoning their way out of political and theological chaos, at a time when no one else saw anything to do but continue fighting an interminable war." 39

\footnotetext{
30. BECKER, supra note 7, at 29-30.

31. Id. at 29 .

32. TOULMIN, supra note 21 , at 22-30.

33. Id. at $55,27$.

34. Id. at $198-201$.

35. Id. at 62 .

36. Id. at 65 . This line from Donne, quoted by Toulmin, is strikingly similar to a line from Yeats' poem, The Second Coming, that is a modern favorite: "Things fall apart; the centre cannot hold."

37. Id. at 65-66, 45-56, 69-71.

38. Id. at 45 .

39. Id. at 71 ; see also id. at 70 ("The 17th-century philosophers' 'Quest for Certainty' was no mere proposal to construct abstract and timeless intellectual schemas,
} 
Thus interpreted, the Enlightenment separation of reason from culture was not necessarily a childish misconception, but rather an effort in improvement and renewal of the sort that admired figures have undertaken at pivotal moments throughout history. Nor should the obvious diversity in conceptions of reason necessarily prove embarrassing. Reason meant, in essence, a human capacity for grasping truth. Just how that capacity functioned was, to be sure, a source of disagreement. So conceptions of reason differed. But it would be wrong to conclude that reason signified nothing more than a word, or a slogan: what held the diverse conceptions together was the shared understanding that reason is a capacity for knowing and living by truth — or by Truth.

The consensus criterion. In different ways, Enlightenment thinkers gravitated to the view that agreement or consensus should serve as a working principle governing the operation of reason. The commitment to what we can call a "consensus criterion" was a natural if complex and sometimes compromised consequence of the component just discussed - the separation of reason from culture.

Indeed, the consensus criterion might seem to be a natural consequence of reason itself. Both before and since the Enlightenment, that is, reason has usually been taken as describing a common human faculty, or even a feature that defines what it means to be human: the human being is supposed to be the "rational animal." And if reason is a common human faculty, then it seems to follow-doesn't it? - that arguments based on reason ought to be able to gain the assent of anyone who will honestly consider them. ${ }^{40}$ In the Middle Ages, however, reason stood as a sort of junior partner to a higher source of truth, "revelation," which operated to guide and correct it. And the exercise of reason depended on training in a large body of philosophical and theological writings that conveyed the truths that reason and revelation had accumulated over the centuries. Thomas Aquinas's Summas were the consummate expression of this medieval enterprise of reason. So it would hardly be surprising if persons untrained and unversed in this

dreamed up as objects of pure, detached intellectual study. Instead, it was a timely response to a specific historical challenge-the political, social, and theological chaos embodied in the Thirty Years' War.").

40. Thus, Aquinas explained that in debating with those who do not accept Christian scripture "[w]e must, therefore, have recourse to the natural reason, to which all men are forced to give their assent." But he quickly added that "in divine matters the natural reason has its failings." SAINT ThOMAS Aquinas, THE SUMma CONTRA Gentiles, I, ch. 2 (Anton C. Pegis trans., 1975 ed.). 
corpus of learning might fail to grasp the truth of vital matters: even what is self-evident, Aquinas explained, may not be self-evident to us. ${ }^{41}$

The point is not that there was anything duplicitous or hypocritical in the medieval view that truths known through reason might nonetheless be accessible only to those who have been properly trained in a body of received learning. Some such qualification will inevitably attend any conception of reason. Thus, Coke made essentially the same point to James I in explaining why the common law, though the perfection of reason, could be known not through the "natural reason" possessed in ample measure by the king, but only through "artificial reason" and with the aid of "long Study and Experience [in the law] before ... a [man] can attain to ... [c] [ognizance of it." ${ }^{\prime 2}$ No doubt students in any complex and developed field - science, math, law-are told the same. In a related vein, Enlightenment thinkers themselves were acutely conscious of the fact that reason cannot operate in people whose minds are befogged by prejudice or passion - or religious enthusiasm or fanaticism. Hence the chant of the aroused French masses-aroused in part by a comely young woman chosen to serve as the "Goddess of Reason"- - outside the newly christened Temple of Reason (the erstwhile Cathedral of Notre Dame): "Reason Forever! Down with fanaticism!"43

Though Americans were a bit calmer, still, as Henry May explains, "[s]elf-evident truth, most of the framers believed, was much more selfevident to some than to others. On the whole government worked best if it remained in the hands of gentlemen of generous education and large views." 44 So Enlightenment reason, it seems, has always understood itself and its claims to be subject to some such "reasonable persons" qualification: reason for the reasonable.

Still, by separating reason from culture, and by purporting to renounce reliance on tradition and authority, the Enlightenment conception necessarily undermined that sort of qualification, and thereby shifted greater emphasis to consensus as a criterion for measuring the successful exercise of reason. If reason is something that all competent persons are capable of, then the results of reasoning ought in principle to be recognizable by all competent persons - not only by people acculturated in a particular religious or political tradition. The ploughman should be

41. Summa Theologica, I.II., Q. 94, A. 1.

42. For a summary of the incident, see Keith E. Whittington, Extrajudicial Constitutional Interpretation: Three Objectives and Responses, 80 N.C. L. REV. 773, 810 (2002).

43. The episode is recounted in 2 AdOlph THIERS, THE History of the French REVOLUTION 370-371 (Frederick Shoberl trans. 1850).

44. MAY, Divided HEART, supra note 10, at 155. 
on a par with the professor. ${ }^{45}$ In this way, Enlightenment reason has a common denominator quality: it steers inquirers away from the particular, ${ }^{46}$ the local, the "sectarian," toward what everyone can understand and accept.

In science (which partisans of Enlightenment have typically regarded as a sort of alter ego, or at least as a brother-subject to the occasional sibling rivalry) ${ }^{47}$ this consensus criterion is expressed in the requirements that observations be mutually verifiable and that experiments be repeatable. Although these requirements cannot be transferred intact to moral and political thought, a similar principle is reflected in the effort to derive conclusions not from authority but rather from reasons and premises whose truth should be apparent to all honest inquirers. Once again, the Declaration of Independence manifests this assumption. It begins by expressing "a decent respect to the opinions" not merely of people brought up in a particular political or religious tradition, but rather "of mankind." 48 And the Declaration goes on to offer what are held out as "self-evident" truths - truths that should be recognizable as such by "a candid world." 49

As the Declaration's language reflects, the overall Enlightenment commitment is still to truth. We are to live by truth, ... which is known by reason, ... the successful operation of which should be reflected in the achievement of consensus among reasonable persons. The connection linking consensus, reason, and truth needs emphasizing because, as we will see, consensus can be sought for purposes other than discerning truth.

Freedom of expression. The association of reason with a consensus criterion is nicely compatible with one more specific political commitment commonly associated with the Enlightenment: freedom of expression. No doubt Enlightenment thinkers varied in the strength and scope of their commitment to free speech. But they tended to favor the

45. Cf. Thomas Jefferson, Letter to Peter Carr (Aug. 10, 1787), reprinted in THE Portable ThOMAs JefFerson 425 (Merrill D. Peterson ed., 1975) ("State a moral case to a ploughman and a professor. The former will decide it as well, and often better than the latter, because he has not been led astray by artificial rules.").

46. Donald Livingston explains that Enlightenment thinkers saw "reason" as the opposite of "tradition" precisely because tradition was an embodiment of "scandalous particularities." LIVINGSTON, supra note 15, at 244.

47. See Peter GAy, The EnLightenMent: An Interpretation 126-29 (1966).

48. THE DECLARATION OF INDEPENDENCE, supra note 8.

49. Id. at para. 2 . 
idea, at least in principle and sometimes in practice ${ }^{50}$-witness Jefferson's and Madison's resistance to the Alien and Sedition Acts-and on their own premises they should have. Freedom of speech is related to a consensus-oriented conception of reason in two ways. First, freedom is a necessary condition of measuring or discerning the existence of consensus. Allowing people to express their views, that is, seems the only way to ascertain whether a real consensus exists: how are we to tell whether people agree unless they are free to say what they think? Second, even where people do not initially agree, an interchange of views seems calculated to lead people in the direction of consensus.

Or does it? The statement admittedly reflects a grand leap of faith - and one that experience over the last two centuries might seem to belie. ${ }^{51}$ Open, candid discussion seems likely to lead in the direction of an agreed upon truth in a given domain on two assumptions: first, that there is in fact a truth to be found in that domain and, second, that thinking and discussing are efficacious means of discerning that truth.52 Conversely, if there is no truth to be discovered in a given domain - the domain of morality, for example - then there is no a priori reason to suppose that open discussion would be likely to lead towards consensus. And if discourse is understood not so much as a means of exchanging ideas about truth but rather in other terms - as an instrument for achieving one's interests, or as a manifestation of personal or collective identity - then there would be little reason to expect free discussion to lead either to truth or to consensus. On the contrary.

So once again, the commitment of the classical Enlightenment to freedom of expression rests on the more fundamental premise that truth,

50. See Rogers M. SMith, Liberalism AND AmERicAn Constitutional Law 9295 (1985 ed.). In this spirit, Kant argued that "[f]reedom of the pen is the sole safeguard of the rights of the people." GAY, supra note 47, at 71. Michael Kent Curtis observes that "[f]or the founding generation, ideas of free speech and press grew in the environment of the Enlightenment." Curtis, Monkey Trials: Science, Defamation, and the Suppression of Dissent, 4 WM. \& MARY BILl RTS. J. 507, 546 (1995).

51. $\quad C f$. Frederick Schauer, Free SPeECH: A PhILOSOPHICAL ENQUIRY 26 (1982).

It is hardly surprising that the search for truth was so central in the writings of Milton, Locke, Voltaire, and Jefferson. They placed their faith in the ability of reason to solve problems and distinguish truth from falsehood. They had confidence in the reasoning power of all people, if only that power were allowed to flourish. The argument from truth is very much a child of the Enlightenment, and of the optimistic view of the rationality and perfectibility it embodied. But the naïveté of the Enlightenment has since been largely discredited by history and by contemporary insights of psychology. Id. (emphasis in original).

52. Cf. Christopher T. Wonnell, Truth and the Marketplace of Ideas, 19 U.C. DAVIS L. REV. 669, 671 (1986) ("The linkage between free speech and truth seemed particularly persuasive to Enlightenment thinkers convinced of the power of human reason."). 
or Truth, exists and that human beings can and should know it and live by it. But what gives plausibility to that sanguine premise? It might almost seem that such a happy state of affairs could exist only in a providentially designed universe - one in which, as Descartes had thought, a benevolent deity could serve as a sort of guarantor of human understanding. ${ }^{53}$ And that, as it happens, was precisely what most Enlightenment thinkers (at least in America) did believe.

A common, providential worldview. The premise positing the existence of Truth and the commensurability of Truth with the human mind was nicely consonant with a worldview that was uniformly embraced by the Enlightened architects of the American constitutional order. "The Constitutional debates," Henry May explains, "reveal beneath fierce disagreements a deep, taken-for-granted unity among Federalists and Antifederalists, conservatives and liberals, the party of commerce and the party of virtue - even between Calvinists and Deists." 54 This agreement extended across a surprisingly broad spectrum of topics: "religion, human nature, theory of knowledge, political theory, history, and the right kind of governing class." 55

One aspect of this consensus deserves special emphasis, both because it may seem surprising to modern thinkers and because, as suggested above, it served as a presupposition for reasoning about the other topics, including those central to American constitutionalism. For much of Western history, the universe had been conceived of as a divinelyinstituted normative order or, as Louis Dupre puts it, an "ontotheological synthesis"; 56 and morality (including political morality) had been understood as the art or practice of living in harmony with that order. Imposing labels anachronistically, we may today suppose that because the Enlightenment was supposed to have been a secular movement rebelling against a tradition that was religious, Enlightenment thinkers must have repudiated this belief in a providential order. But this supposition turns history on its head. Not only did the classical Enlightenment retain a faith in the existence of a normative cosmic

53. DESCARTES, supra note 4, at 21-22.

54. MAY, DIVIDED HEART, supra note 10, at 147-48 (emphasis omitted).

55. Id. at 150 .

56. Dupre explains that in classical thought, the universe was viewed as a "kosmos," or as an "ontotheological synthesis," in which nature itself was thought to have "theological and anthropic as well as physical meanings." LOUIS DUPRE, PASSAGE to Modernity: An Essay in the Hermeneutics of NAture and Culture 3, 11, 18 (1993). 
order; the accomplishment of thinkers like Locke, as Carl Becker noted, was precisely to subvert religious doctrines, such as the Calvinist doctrine of depravity, that had undermined confidence in the capacity of human beings to comprehend and conform to that overarching order. ${ }^{57}$

The assumption of a providential order pervaded Jeffersonian thinking and provided the premise for reasoning on questions of all kinds-moral, political, or scientific. Was the earth created much as it is now? Or did it evolve over a long period of time? Do mammoths still exist? Do human beings have natural rights beyond the positive legal rights conferred on them by particular legal systems? Jefferson's answers to these questions (respectively yes, no, yes, yes) all derived from his belief in an overarching providential order in the universe. ${ }^{58}$ In particular, the providential framework provided the basis for specific commitments to natural or human rights. For Jefferson, as Daniel Boorstin puts it, "no claim[] [of rights] could be validated except by the Creator's plan..... ${ }^{59}$ The essential idea is succinctly expressed, once again, in the Declaration: ${ }^{60}$ "We hold these truths to be self-evident, that all men are created equal, that they are endowed by their Creator with certain unalienable rights ...."61

The unapologetically religious character of eighteenth-century Enlightenment discourse, and more specifically its persistent reliance on the premise of a providential order, may be disconcerting to modern heirs of the Enlightenment. ${ }^{62}$ And indeed, the divergence in this respect

57. BECKER, supra note 7, at 64-65.

58. Overwhelming evidence for this assertion is marshaled in DANIEL J. BOORSTIN, THE LOST WORLD OF THOMAS JEFFERSON 194, 196 (1993). I give a succinct summary of the evidence from Boorstin and a few other sources, as well as citations for the specific questions mentioned in the text, in Steven D. Smith, Nonsense and Natural Law, in PAUL CAmpos, et Al., Against the LAW 100 (1996). See generally Henry F. May, The ENLIGHTENMENT IN AMERICA (1976).

59. BOORSTIN, supra note 58, at 196. "The word 'right' was always a signpost pointing back to the divine plan of the Creation." Id. at 194.

60. THE DEClARATION OF INDEPENDENCE, supra note 8, at para. 2 (emphasis added).

61. Cf. George P. Fletcher, In God's Image: The Religious Imperative of Equality Under Law, 99 COLUM. L. REV. 1608, 1611 (1999) ("Behind those created equal stands a Creator, who is the source of our inalienable rights 'to life, liberty, and the pursuit of happiness."'). For a contrary interpretation that makes the "Creator" largely synonymous with a not necessarily theistic "nature," see MiCHAEL P. ZUCKERT, THE NATURAL RightS REPUBLIC 41-55 (1996).

62. Henry F. May explains that "neglect of religion or of theology is one common error among historians of the Enlightenment," and he offers a hypothesis about how a "homogenized version of the Enlightenment" that downplayed its religious dimension came to prevail:

In America [this depiction] comes mostly ... from the . . . moderate and liberal left to which most of us academics usually give our allegiance. This version, I think, reached its greatest strength in America in the late nineteenth and early twentieth century among pragmatic social scientists, among them James 
between classical Enlightenment thought and more modern thinking of an Enlightenment bent reflects a crucial divide between the classical and modern Enlightenments. In the eighteenth-century context, though, reasoning on the assumption of an overarching normative order was entirely compatible with the Enlightenment conception of reason.

Reason, as noted, entailed a search for the common denominator-for what seemed true to everyone, regardless of the particularities of culture or the idiosyncrasies of the individual believer. But in the America of the founders, nearly everyone adhered either to some species of Protestantism or to some Protestant offshoot-unitarianism, deism, rational or natural religion. These diverse faiths shared a belief in a divine Author or Architect who created the universe according to an intelligent and benevolent plan. The few Catholics and even fewer Jews who might have registered on the Americans' intellectual landscape would not have dissented from this general proposition. And there were, James Turner argues, literally no atheists detectable on the scene-or at least none other than perhaps Joel Barlow. ${ }^{63}$

In this context, the belief in a divinely-ordained normative order had a nonsectarian quality - or at least it could seem to have this quality to the responsible, disciplined mind that did not allow itself to rove too far beyond the immediate "live" intellectual options or to dwell on exotic possibilities. No doubt a person of learning, like Jefferson, was aware at least on a purely cognitive level that in the far reaches of the world (or even in places he had visited-France, for instance) there were, for example, genuine atheists. But this remote fact need not disturb the present working consensus any more than a brief occasional encounter with believers in reincarnation troubles a modern Western secularist. ${ }^{64}$

Harvey Robinson and, in far less naïve form, John Dewey. These men, like many others in all periods and especially in the eighteenth century, tended to think that all history inevitably led to themselves. Thus, as they saw it, the "mind of the eighteenth century" moved gradually from orthodoxy to natural religion to deism and finally to pragmatic secularism.

HENRY F. MAY, IDEAS, FAITHS, AND FEELINGS 131, 135 (1983) [hereinafter MAY, IDEAS]. 63. What the orthodox called "atheism" usually amounted to nothing but a Deistic denial of revealed religion.... If one disregards the expatriate Barlow just before 1800, America does not seem to have harbored a single individual before the nineteenth century who disbelieved in God.... For disbelief in God remained scarcely more plausible than disbelief in gravity.

James Turner, Without God, Without Creed: The Origins of Unbelief IN AMERICA $44(1985)$

64. Cf. John R. Searle, The Rediscovery of the Mind 91 (1992) (describing a personal encounter with believers in reincarnation): 
If reason sought the common denominator, in short, the providential worldview was the common denominator. Indeed, in the eighteenthcentury climate of opinion, it would have been against reason to doubt the providential worldview. "All believed in a universe that was presided over by a benevolent deity, a universe that made sense in human terms and was intelligible to human reason," Henry May observes. ${ }^{65}$ So "most if not all of the framers would have found it impossible to imagine any other kind of universe."

The eighteenth-century convergence. In sum, the classical Enlightenment reflected a happy convergence of elements. A universe designed and governed by a benevolent providence provided the Truth by which people might aspire to live - a Truth that transcended any particular culture, and that was knowable because it was providentially commensurate with the operations of the human mind. Through free and honest discussion people might hope to come ever closer to a full and shared understanding of this Truth.

\section{THE MODERN IDEAL: INVERTING THE ENLIGHTENMENT}

The historical Enlightenment, as noted, is often said to have dissolved in the nineteenth century. But many modern political and constitutional theorists continue to invoke it - or to have it invoked in their behalf-in support of a liberal vision of American constitutionalism. So how is the modern ideal related to the classical position just discussed?

In addressing this question, a preliminary caution is in order. The modern Enlightenment, like the classical one, is "necessarily rather amorphous and diverse." ${ }^{97}$ So what I will be calling "the Enlightenment ideal" will again reflect a selective and contestable interpretation. Its contestability will be especially conspicuous because, unlike Descartes and Jefferson, the partisans of the modern Enlightenment are our friends

When I lectured on the mind-body problem in India and was assured by several members of my audience that my views must be mistaken, because they personally had existed in their earlier lives as frogs or elephants, etc., I did not think, "Here is evidence for an alternative world view," or even "Who knows, perhaps they are right." And my insensitivity was much more than mere cultural provincialism: Given what I know about how the world works, I could not regard their views as serious candidates for truth.

65. MAY, DIVIDED HEART, supra note 10, at 151.

66. Id. For a similar argument, see Sidney E. MEAD, The Nation with THE Soul OF A CHURCH 18-20 (1975). Mead argues that "most of the men who had a hand in framing the Declaration and the Constitution and in launching the new government" acted on the basis of a sort of "theology of the Republic." This theology was not "distinctively Protestant or even Christian." At the same time, "those who try to make secularists - in the classical sense - out of [the framers] are just as wrong" as those who argue for a Protestant or Christian founding. Id. at 21.

67. See PORTER, supra note 3. 
and neighbors (and often ourselves); we know that their views - or our views - are complex, and that we differ among ourselves, and that not everyone who might be classified as a partisan for present purposes will happily claim to descend from the Enlightenment. Some, such as Rawls, may even try to distance themselves from it. Rawls - that "titan of our age" ${ }^{\prime 6}$ - is an especially troublesome case. I think that he must be taken as the most influential contemporary American theorist of the Enlightenment ideal, ${ }^{69}$ and that any discussion of that ideal needs to refer to ideas associated with him. Yet, not only does Rawls disclaim the label — or at least qualify it ${ }^{70}$ — but his position is highly complicated and, it seems, ever developing, and the interpretation and criticism or defense of Rawls has become, in some academic quarters, a less than magnificent obsession. That is not an obsession that we should allow to consume us here. So let it be clear that my purpose in what follows is not to offer a definitive interpretation of Rawls - or any other particular thinker - but rather to try to extract a sort of ideal or orientation that, subject of course to variations and different degrees of commitment, animates a good deal of the thought of influential theorists such as Rawls, Stephen Macedo, Martha Nussbaum, Robert Audi, Amy Gutmann, Thomas Nagel, Ronald Dworkin, Bruce Ackerman, and Kent Greenawalt, and that has discernible if complicated effects on actual constitutional decisions and doctrines.

The ongoing commitment to reason. The most obvious connection linking the modern ideal to the historical Enlightenment is a shared professed commitment to governance in accordance with reason. Modern theorists enthusiastically embrace the vocabulary of reason -indeed, one sometimes wonders whether their word processors have been infected with a virus that spreads the word "reason" and its cognates through

68. Michael P. Zuckert, Is Modern Liberalism Compatible with Limited Government? The Case of Rawls, in NATURAL LAw, LiBERALISM, AND Morality 49, 80 (Robert P. George ed., 1996).

69. Rawls's position is routinely understood to be in the tradition of Kantian liberalism. Cf. RICHARD RORTY, Religion as Conversation-Stopper (1994), in PHILOSOPHY AND SOCIAL HoPe 168, 170 (1999) (describing Rawls and Habermas as "the two most prominent social thinkers of the present day, and of the central secularizing message of the Enlightenment").

70. Rawls asserts that his position is unlike "Enlightenment liberalism" in that it does not present liberalism as a comprehensive doctrine and does not attack orthodox Christianity. JOHN RAWLS, POLITICAL LIBERALISM xl (paperback ed. 1996) [hereinafter Rawls, PL]; John Rawls, The Idea of Public Reason Revisited, in The LAw OF PEOPLeS 131, 176 (1999) [hereinafter RAwLs, Public Reason]. 
their writings like an epidemic ${ }^{71}$ - and, moreover, their understanding of reason exhibits important resemblances to the Enlightenment conception. Most significantly, modern heirs to the Enlightenment legacy persist in emphasizing the distinction separating reason from culture and tradition. And they claim to embrace the consensus criterion at least as warmly as the historical figures did.

These aspects of Enlightenment reason are readily apparent in Rawls's influential writings. The ideal of a political community shaped by and committed to "public reason" pervades Rawls's thought. And despite other differences from his historical forbears, ${ }^{72}$ Rawls's notions of reason have a distinctly Enlightenment cast. The separation of reason from culture and tradition is reflected in Rawls's insistence that public reason must remain "freestanding" and independent of any and all "comprehensive doctrines"73 - views which might well grow out of and reflect particular cultures or intellectual traditions. Instead, the content of reason is confined to "presently accepted general beliefs and forms of reasoning found in common sense, and the methods and conclusions of science when these are not controversial." ${ }^{, 74}$ By confining reason to these largely uncontested materials, Rawls hopes to build on and secure an overlapping consensus among reasonable views. ${ }^{75}$

Although theorists differ among themselves, Rawls's vision of public reason is in essential respects much like the "democratic deliberation" favored by other theorists. In an essay advocating what he calls "liberal public reason," Stephen Macedo notices the common themes uniting the public reason of theorists like Rawls and the "deliberative democracy" of theorists like Amy Gutmann and Dennis Thompson. ${ }^{76}$ These common themes, moreover, are precisely those that flow from the Enlightenment conception of reason, with its consensus criterion. ${ }^{77}$ The core demand is that public deliberation should "be carried on in terms that are mutually acceptable," not on the basis of "sectarian" views. ${ }^{78}$

In this particular, therefore, modern liberal theorists can plausibly claim to be faithful heirs of the Enlightenment. In other respects,

71. See, e.g., RAWLS, PL, supra note 70, at li ("[W]e must give them reasons they can not only understand ... but reasons we might reasonably expect that they as free and equal might reasonably also accept.").

72. See supra note 70.

73. See RAWLS, PL, supra note 70, at xxxix-lvii, 212-54.

74. Id. at 224 .

75. Id. at 134 .

76. Stephen Macedo, In Defense of Liberal Public Reason: Are Slavery and Abortion Hard Cases?, in NATURAL LAw AND Public ReAson 11, 13, 25-26 (Robert P. George \& Christopher Wolfe eds., 2000).

77. Cf. RORTY, supra note 14, at 173 (describing "consensus" as "the test of a belief" in a democracy).

78. Macedo, supra note 76 , at 25. 
though, they depart from the classical position. The departures are not minor; moreover, they have the effect of turning essential Enlightenment aspirations upside down.

The disintegration of the classical position. In the eighteenth century, the components discussed above seemed nicely harmonious. But two centuries later, this happy congruity has been decisively shattered. The breakdown of the eighteenth-century convergence has been in large measure a result of several currents, ironically, that are often associated with the Enlightenment itself. We can briefly notice three such developments: democracy, pluralism, and secularism.

Though modern partisans of Enlightenment (such as, outstandingly, Dewey) may claim "democracy" for their cause, the thinkers of the historical Enlightenment were typically not greatly enamored of democracy. ${ }^{79}$ Henry May argues that both in Europe and in America, the partisans of Enlightenment were generally suspicious of "the masses," and that the major democratizing force was in fact radical Protestantism. ${ }^{80}$ Nonetheless, the Enlightenment commitment to equality (expressed in the Declaration of Independence) together with the acceptance of consensus as the criterion of reason contained a democratizing impulse-one that played itself out over the next two centuries through enlargement of the franchise, expansion of educational opportunities, and in other ways. One result of this development was that the number of people who presumptively "counted" for purposes of determining the existence of a consensus multiplied dramatically. This expansion, we might surmise, would almost necessarily make the achievement of a genuine consensus on momentous issues more difficult. The difficulty would be compounded by the increasing pluralism-religious, political, cultural-that, as theorists like Rawls stress, now appears to be a natural and irreversible accompaniment of Enlightened political commitments to freedom of religion and freedom of expression. ${ }^{81}$

If democracy and pluralism hindered the achievement of consensus by multiplying viewpoints, an evolving secularism undermined the

79. Cf. Robert K. Faulkner, Jefferson and the Enlightened Science of Liberty, in REASON AND REPUBLICANISM: THOMAS JEFFERSON's LEGACY OF LIBERTY 31, 34 (Gary L. McDowell and Sharon L. Noble eds., 1997) (noting that "[w]hile Jefferson celebrated a self-governing people, he despised and feared city mobs and, in general, the unenlightened").

80. MAY, Divided HEART, supra note 10, at 163-66.

81. See RAWLS, Public Reason, supra note 70, at xviii, xxiv. 
particular basis for consensus that the eighteenth century had enjoyed. As discussed, the so-called "secularism" of the classical Enlightenment had seemed compatible with a providential worldview, but this partnership dissolved as, among other things, modern science offered a new vision of how the universe is constituted. Though it now appears that secularization is neither as uniform nor as inexorable as it once seemed, ${ }^{82}$ it still dominates some sectors of the culture, especially the academy (which of course imagines itself to be the main bastion of Enlightenment) $;^{83}$ and one consequence of that change has been that in those sectors the belief in a divinely-established normative order, widely shared in the eighteenth century, has by now come to seem at best highly sectarian.

As these developments have subverted the comfortable alliance among the components of the eighteenth-century Enlightenment, the meaning of the slogan of reason, or of a collective life governed by reason, has changed as well, becoming in important ways just the opposite of the classical meaning.

Reason or Truth? Most fundamentally, the classical belief that reason is valuable as an adjunct to the commitment to living in accordance with Truth has given way to a radically altered understanding in which reason - or at least the kind of public reason that is supposed to govern the political community - is carefully and deliberately insulated against questions and claims of Truth.

The first step in the divorce of reason from Truth comes with the conclusion that reason should be independent of religious premises or values, or of a religious worldview. Religious beliefs, after all, cannot satisfy the consensus criterion that is the working principle of reason. Purged of religion, public discourse becomes secular. ${ }^{84}$ In this spirit,

82. See Peter L. Berger, The Desecularization of the World: A Global Overview, in The Desecularization of the World: Resurgent Religion AND World Politics 1-3 (Peter L. Berger ed., 1999).

83. See id. at 10 ("There exists an international subculture composed of people with Western-type higher education, especially in the humanities and social sciences, that is indeed secularized. This subculture is the principal 'carrier' of progressive, Enlightened beliefs and values.").

84. This sentence admittedly glosses over major difficulties. From the fact that Enlightenment reason no longer supports the providential worldview within which the founding generation operated, does it logically follow, one might ask, that this conception does impel us to adopt a "secular" worldview or discourse? Isn't that worldview also controversial — and hence ruled out by the consensus criterion? The modern partisan of Enlightenment is likely to respond, I think, that a secular worldview is uncontroversial (among properly educated and "reasonable" people, at least), or that a secular worldview is "neutral" among the controversial alternatives, or that a secular worldview is what we are left with by default from the inability of "reason" to support any more theologically or metaphysically ambitious worldview. All of these responses are deeply problematic, but for immediate, mainly descriptive purposes we need not be 
Kathleen Sullivan asserts that the United States Constitution brought about "the establishment of the secular public order." ${ }^{85}$ And the modern Supreme Court has stumbled in the general direction of this conclusion. Thus, modern establishment doctrine, though notoriously capricious in its operations, at least purports to limit government to acting for secular purposes and in ways that have primarily secular effects. ${ }^{86}$

The requirement of secularity limits what government can $d o$ (as well as why government can do what it does); it also regulates what government can say. This kind of regulation is evident in the "endorsement" construction that has been added to establishment doctrine over the last couple of decades. Though implementation has been erratic, current doctrine holds that government cannot do or say anything that sends a message endorsing or disapproving of any religion. ${ }^{87}$ This prohibition has the effect of discouraging the inclusion of religion in public decision making, because religious statements offered in support of a measure may condemn it by causing the measure to be perceived as an endorsement of religion. ${ }^{88}$

Notice that the exclusion of religion from public decision making is not based — not officially, at least - on any assumption that religion is false. Indeed, defenders of current doctrine insist on the point: The secularity requirement is supposed to be simply "neutral" toward

too scrupulous on this point.

85. Kathleen M. Sullivan, Religion and Liberal Democracy, 59 U. CHI. L. REv. 195, 201 (1992).

86. Lemon v. Kurtzman, 403 U.S. 602, 612-13 (1971), aff'd 411 U.S. 192 (1973).

87. See, e.g., Capitol Square Review Bd. v. Pinette, 515 U.S. 753, 766-70 (1995).

It is sometimes noted that the prohibition on endorsement of religion, at least by any unstrained interpretation, would render problematic if not flatly invalidate a host of measures and pronouncements that have often been counted as part of the core of the American political tradition-significant parts of Jefferson's Virginia Statute for Religious Liberty, the Declaration of Independence, Washington's Farewell Address and the Gettysburg Address and all of Lincoln's Second Inaugural Address, as well as the national motto and the Pledge of Allegiance - because of their explicit religious content. Some of these pronouncements - in particular, Jefferson's religious freedom statute and the Declaration of Independence - were monuments of the classical Enlightenment in America. Thus, the widespread appeal of the "no endorsement" principle dramatically illustrates the modern shift away from the classical Enlightenment.

88. See, e.g., Wallace v. Jaffree, 472 U.S. 38, 61 (1985) (striking down a "moment of silence" law under the particular circumstances of the case in part because of statements by the sponsor which the Court took to express a religious purposepromoting prayer in public schools). For a critical discussion of this and similar cases, see Steven D. Smith, Getting Over Equality: A Critical Diagnosis of Religious FREEDOM IN AMERICA 116-34 (2001). 
religion. ${ }^{89}$ And Rawls maintains - though many critics and even supporters remain unpersuaded - that his own version of political liberalism does not pass judgment on the truth of religious or other comprehensive views - even of those declared to be unreasonable..$^{90}$ Hence, both the secularity requirement of constitutional doctrine and the Rawlsian notion of public reason purport to be compatible with the possibility that religion is a source or manifestation of important truths. But it is simply not the role of government - and of the reason that is supposed to guide government - to concern itself with such truths.

Though religion is the most conspicuous of the belief systems to be excluded from the domain of public reason, as currently conceived, it is not the only one. After all, if there is no consensus supporting religion, or any particular religion, there is probably no consensus in favor of any other general view or philosophy of life, human nature, or morality. Thus, theorists like Rawls and Macedo are clear that no "comprehensive conception of truth and the human good as a whole," ${ }^{11}$ religious or secular, can properly be invoked in the exercise of public reason.

By excluding any comprehensive view of truth from the domain of public reason, theorists like Rawls and Macedo deflect the suspicion that they are simply hostile to religion. But they also make it clear that reason, for all of its prominence in their positions, is no longer serving the function of guiding people to live in accordance with Truth. ${ }^{92}$ That sort of Truth, rather, is beyond the purview of reason, or at least of public reason; it is something for people to pursue individually or in private associations. Public reason is now seen as serving other, more

89. For critical discussion, see Steven D. SMith, Foreordained Failure: The QUEST FOR A CONSTITUTIONAL PRINCIPLE OF RELIGIOUS FREEDOM 81-84 (1995).

90. For a careful exposition and critical analysis of Rawls's position on this point, see J. JudD Owen, RELigion and the Demise of Liberal Rationalism: The Foundational CRisis of the Separation of Church and State 100-21 (2001). In a laudatory essay, Edward Foley quotes a passage in which Rawls denies that political liberalism reflects a judgment about the truth of an "unreasonable" religious position, but Foley adds in a footnote: "I confess I am not altogether sure about the meaning of this passage. It seems to me that liberalism does reject as false, as well as unreasonable, the idea that the state must endorse a particular creed if the people are to avoid eternal damnation." Edward B. Foley, Political Liberalism and Establishment Clause Jurisprudence, 43 CASE W. RES. L. REV. 963, 975 \& n.40. (1993) (emphasis in original). Foley goes on to list other religious beliefs that the liberal state must regard as false, and he cites language in which Rawls himself seems, though perhaps inadvertently, to acknowledge this fact. $I d$. at 976-78.

91. Macedo, supra note 76, at 18.

92. The theorists are perfectly candid on this point. Macedo explains, for example, that "philosophical and religious views... proceed from the point of view of a comprehensive conception of truth and the human good as a whole." But "in the modern world, ... people disagree about their views of truth as a whole," and consequently such views are not appropriate bases for public discourse. Macedo, supra note 76, at 18 (emphasis added). 
political and social values such as cooperativeness, reciprocity, and a common citizenship. ${ }^{93}$

Indeed, it would be at most a slight exaggeration to say that whereas in the classical Enlightenment the purpose of reason was to orient discourse toward Truth, under the modern ideal the purpose of public reason is precisely to prevent the introduction of questions and claims about Truth from entering into public discourse. The commitment to reason gradually evolves - or deteriorates - into a commitment to reasonableness, ${ }^{94}$ which consists precisely of a willingness (in the interests of fairness and "getting along") to refrain from pushing reason too deep or too far. ${ }^{95}$ In a humorous mood, Michael Zuckert captures the change by imagining a comment of Calvin on the modern posture (though the comment might as well come from the signatories of the Declaration of Independence who, as noted, pledged all they had in the defense of what they took to be self-evident truths):

For shame, Professor Rawls. Is a bit of threat to your comfort and safety all it takes to scare you off your "convictions"? ... Do you men of Harvard know nothing of truth? Martin Luther said, "Here I stand, I can do no other." He knew the princes of church and state would give him no peace, no rest, yet he stood. And you Harvard philosophers, what do you say? "Here I sit. I dare do no more." 96

By separating reason from truth in a large sense, or from the "whole truth," the modern ideal inverts the classical position. And that inversion manifests itself in other aspects of the modern ideal as well.

The instrumentalization of discourse. The rejection of a providential

93. Id. at $23-24$

94. See Jody S. Kraus, Political Liberalism and Truth, 5 LegAl THEORY 45, 55 (1999) ("Political liberalism's preferred strategy is to substitute the idea of reasonableness for truth.").

95. The development I have in mind here arguably separates not only the classical Enlightenment from the modern one; it also divides an early pragmatist philosopher such as Peirce from a contemporary one like Rorty. In a dialogue constructed from quotations from these two philosophers, Susan Haack nicely captures the difference. SUSAN HAACK, "We Pragmatists ...": Peirce and Rorty in Conversation, in MANIFESTO OF A Passionate Moderate 31-47 (1998). Here is Rorty: "[The] pragmatist view [is] of rationality as civility, ... of 'true' as a word which applies to those beliefs upon which we are able to agree ...." Now Peirce: "You certainly opine that there is such a thing as Truth. Otherwise, reasoning and thought would be without a purpose." Id. at 32.

96. ZuCKERT, supra note 68, at 72. Cf. OWEN, supra note 90, at 127 ("The 'virtue' of getting along, of not insisting on anything (too) controversial, is elevated by Rawls to the highest possible plane.... Nothing, Rawls tells us, can be so important that it is worth disrupting the peaceful scheme of social cooperation."). 
worldview - and the exclusion of "comprehensive views" generally from public reason-means that reason cannot operate in the same way it did in the classical scheme of things. So how is reason to work in public decision making without violating the consensus criterion?

The most tempting prospect is to view reason in instrumental or means-end terms - as a method for figuring out how to achieve shared goals in the most efficient way. Not surprisingly, instrumentalism dominated much of twentieth-century legal thought. ${ }^{97}$ And the Supreme Court has often imported an instrumental conception of reason into its doctrines. ${ }^{98}$

Instrumental reasoning is apt enough when shared goals or values in fact exist and the question is how best to realize them. With respect to other kinds of questions, however, instrumental reasoning seems less efficacious. It has little to say, for example, on vital questions of distributive justice. ${ }^{99}$ In addition, instrumental rationality, though it may provide valuable clarification of alternatives, stands mostly mute before controversies primarily reflecting deep-seated differences in values or moral commitments - such as abortion or affirmative action. Perhaps most fundamentally, means-end reasoning is largely powerless to provide justifications for the most fundamental commitments of the American constitutional order, such as the truths of equality and natural rights asserted in the Declaration of Independence. The problem deserves further explanation.

The problem of justification. The possibility of devising satisfying justifications for central commitments to things such as equality and human rights is of course a controversial matter about which volumes have been written; here we can only notice the difficulties. But it is no

97. See generally Robert SAmuel Summers, InStrumentalism AND AMERICAN LEGAL THEORY 35 (1982).

98. Robert Nagel has perceptively discussed the surprisingly uniform methodology adopted by the United States Supreme Court across a large variety of seemingly disparate constitutional provisions. Whether the subject matter is commercial speech, gender classifications, abortion, or state regulation of interstate commerce, "the Court strikes the same chord again and again: the government must justify its rules by articulating a sufficiently important purpose and by demonstrating that the rule in some degree will actually achieve that purpose." RoBERT F. NAGEL, CONSTITUTIONAL Cultures: The Mentality and ConseQuences of Judicial Review 106-07 (1989). This monotonous demand for "means/end" rationality cannot be explained, Nagel argues, by anything in the text of the diverse provisions the Court purports to apply; rather, it reflects the influence of "general intellectual fashion." Id. at 107, 110.

99. $C f$. Richard A. Posner, ECONOMIC ANAlysis OF LAW 287 (5th ed. 1998) ("[T]he efficiency ethic takes the existing distribution of income and wealth, and the underlying human qualities that generate that distribution, as given, and within very broad limits (what limits?) is uncritical of the changes in that distribution that are brought about by efficient transactions between persons unequally endowed with the world's tangible and intangible goods."). 
secret that the problem of providing a persuasive philosophical justification for rights is a daunting one. ${ }^{100}$ Arguments about equality are similarly voluminous and complex, but it may be worth considering one analysis directly relevant to the issue here.

In an essay called On Equal Human Worth: A Critique of Contemporary Egalitarianism, Louis Pojman notes that an assumption that all humans are of equal worth is central to virtually all modern political theorizing. ${ }^{101}$ But what is the justification for this assumption? The notion of equal worth is hard to square with the empirical evidence:

Take any capacity or ability you like: reason, a good will, the capacity to suffer, the ability to deliberate and choose freely, the ability to make moral decisions and carry them out, self-control, sense of humor, health, athletic and artistic ability, and it seems that humans ... differ in the degree to which they have those capacities and abilities. ${ }^{102}$

Pojman reinforces the point with almost gruesome vividness. Referring to an essay in which Gregory Vlastos imagines humans explaining to a Martian visitor that the "human worth" of all persons is equal, Pojman proceeds to imagine the Martian's response:

He invites Vlastos to consider Smith, a man of low morals and lower intelligence, who abuses his wife and children, who hates exercising or work, for whom novels are dull and art a waste of time, and whose joy it is to spend his days as a couch potato, drinking beer, while watching mud wrestling, violent sports, and soap operas on TV. He is an avid voyeur, devoted to child pornography. He is devoid of intellectual curiosity, eschews science, politics,

100. Noting that the adopters of the Universal Declaration of Human Rights deliberately avoided the problem of justification - one drafter insisted that the proposed Declaration "was based on no philosophy whatsoever"-Mary Ann Glendon explains the difficulty: rights today are usually tied to "human dignity," and

$[\mathrm{t}]$ he common secular understandings are that human beings have dignity because they are autonomous beings capable of making choices (Kant), or because of the sense of empathy that most human beings feel for other sentient creatures (Rousseau). But the former understanding has alarming implications for persons of diminished capacity, and the latter places all morality on the fragile basis of a transient feeling.

Mary Ann Glendon, Foundations of Human Rights: The Unfinished Business, 44 Aм. J. JURIS. 1, 1-2, 12-13 (1999). Michael Perry, a long-standing proponent of human rights, concedes that the justification for human rights is perhaps the only essential matter of public concern for which no secular justification is available: human rights, Perry concludes, are "ineliminably religious." MichaEl J. PERRY, THE IDEA OF HuMAN Rights: FOUR INQUIRIES 11-41 (1998).

101. Louis P. Pojman, On Equal Human Worth: A Critique of Contemporary Egalitarianism, in EQUALITY 282 (Louis P. Pojman \& Robert Westmoreland, eds., 1997).

102. Id. at 294. 
and religion, and eats and drinks in a manner more befitting a pig than a person. Smith lacks wit, grace, humor, technical skill, ambition, courage, self-control, and wisdom. He is anti-social, morose, lazy, a freeloader who feels no guilt about living on welfare, when he is perfectly able to work, has no social conscience, and barely avoids getting caught for his petty thievery. He has no talents, makes no social contribution, lacks a moral sense.... But Smith is proud of one thing: that he is "sacred," of "infinite worth," of equal intrinsic value as Abraham Lincoln, Mother Teresa, Albert Schweitzer, the Dalai Lama, Jesus Christ, Gandhi, and Einstein. ... From the egalitarian perspective, ... Smith is of equal intrinsic worth as the best citizen in his community. We could excuse the Martian if he exhibited amazement at this incredible doctrine. 103

So then what is the justification for saying that all persons are in some important sense of equal worth? Pojman argues that as a historical matter, the idea of human equality descends from a religious tradition. ${ }^{104}$ Often the justification takes the form of a claim that all humans are made by, and in the image of, God. ${ }^{105}$ The justification is also expressed in the imagery of family: "The language of human dignity and worth implies a great family in which a benevolent and sovereign Father binds together all his children in love and justice."106 And that rationale can be given more analytical form: Pojman identifies two principal justifications in the religious tradition, which he calls "the Essentialist Argument" and "the Argument from Grace."107

But these are precisely the sorts of rationales that an Enlightened public reason seeks to filter out of public discourse and public justification. "What distinguishes most contemporary egalitarianism from earlier natural law modes is its self-conscious secularism," Pojman observes. ${ }^{108}$ "There is no appeal to a God or a transcendental realm."109 So Pojman examines ten leading secular arguments advanced by theorists such as Ronald Dworkin, John Rawls, Kai Nielsen, Joel Feinberg, Thomas Nagel, and Alan Gewirth; and he finds all of these arguments wanting. ${ }^{110}$ Sometimes the arguments turn on demonstrable fallacies or on flagrant and unsupported discursive leaps; more often,

103. Id. at 287

104. Id. at 295 .

105. "The argument implicit in the Judeo-Christian tradition seems to be that God is the ultimate value and that humans derive their value by being created in his image and likeness." Id. at 295. Cf. Glendon, supra note 100, at 13 ("Most believers . . would say that dignity is grounded in the fact that human beings are made in the image and likeness of God, but that proposition is unintelligible to nonbelievers."').

106. Pojman, supra note 101, at 295.

107. The first argument holds that "God created all humans with an equal amount of some property $\mathrm{P}$, which constitutes high value." The second argument suggests that "actual value may be different in different people but grace compensates the differences." Id.

108. Id. at 282 .

109. Id.

110. Id. at $283-94$. 
they do not actually offer any justification for equality at all, but instead simply assert or assume it, or else posit that in the absence of any persuasive justification one way or the other we should adopt a "presumption" of equal worth. ${ }^{111}$

Pojman concludes that egalitarian commitments are "simply a leftover from a religious world view now rejected by all of the philosophers discussed in this essay." 112 Secular egalitarians are free riders, living off an inheritance they view with disdain. And he wonders whether "perhaps we should abandon egalitarianism and devise political philosophies that reflect naturalistic assumptions, theories which are forthright in viewing humans as differentially talented animals who must get on together." 113

In sum, divorcing reason from any comprehensive views - and in particular from the providential worldview widely held during the American founding - pushes reason in a secular and instrumentalist direction. But it is doubtful that mere instrumental and secular rationality, for all their uses, can justify the most basic commitments of the American constitutional order.

Manufacturing - and manipulating-consensus. Responses to this challenge vary, of course, but it seems that the characteristic stance of modern liberal theorists of an Enlightenment bent, following the example of the architects of international human rights, ${ }^{114}$ is simply to spurn the demand for justifications and to base the central commitments to equality and rights on an ostensible consensus within the relevant constituency. George Fletcher observes in this vein that

[m]odern philosophical approaches toward equality ... are strongly committed, vaguely, to some position on the spectrum, but they offer no reason why they are so intensely committed to this value .... In the contemporary liberal culture, equality is one of those values that has become so deeply held that it is neither questioned nor justified. 115

111. Id.

112. Id. at 283

113. Id. at 296. For an analysis closely paralleling Pojman's in important respects, see Fletcher, supra note 61; GeOrge P. Fletcher, Our SeCret Constitution: How LinCOln REDEFINED AMERICAN DEMOCRACY 91-105 (2001). See generally Jeremy WALDRON, GOD, LOCKE, AND EQUALITY (2002) (arguing that Locke's commitment to equality was firmly based in religious assumptions, and that modern efforts to support the commitment have not to this point succeeded).

114. See supra note 100.

115. Fletcher, Our SeCret Constitution, supra note 113, at 95-96; cf. Patrick McKinley Brennan, Arguing for Human Equality, 18 J.L. \& RELIGION 99, 121 (2002) ("[T]he persistent inquirer finds a sort of pseudo-analytic house-of-mirrors, of the sort 
This stance might seem to be a blatant abdication of the Enlightenment demand that all practices and beliefs be justified by reason. Still, there is a nice logic to the position. After all, the demand for justifications may plausibly be understood as asking that partisans of liberal constitutionalism show how their commitments are derived from a persuasive comprehensive view - or from Truth. Eighteenth-century justifications took that form, as we have seen. But of course this sort of argument from Truth is precisely what modern public reason seeks to discourage, at least as part of public discourse. So any attempt at justification in this sense arguably betrays the modern Enlightenment ideal. ${ }^{116}$ Conversely, modern reason still embraces the consensus criterion. And the happy fact is, Stephen Macedo argues, that "America does enjoy a widespread consensus on basic guarantees that constitute the core of a political morality" including commitments to "fair cooperation, civility among citizens who disagree reasonably, a belief in basic liberties, and due process and the rule of law." 117

Though it is nicely congruent with the modern Enlightenment orientation, however, this philosophically demure, consensus-oriented approach remains vulnerable to potent objections. In the first place, the core political ideals are not supported by any universal consensus. Even the broad ideals of the Declaration of Independence - human equality, natural or human rights - do not enjoy any consensus across the spectrum of world cultures. ${ }^{118}$ So the consensus on which modern partisans of Enlightenment rely seems limited to the people of liberal

that fortifies Michael White's judgment that equality-talk is destined for triviality, if not downright dishonesty.").

116. In this vein, J. Judd Owen explains that "Rawlsian liberalism's desire to refrain from touching upon the truth of any comprehensive doctrine whatever entails a silence about its own truth"; consequently, "the justification of liberalism cannot be part of liberalism proper." OWEN, supra note 90, at 109. For the same reason, Owen claims, " "public reason' cannot itself be justified or even argued for with public reasons. It can only be asserted." Id. at 120. Though he criticizes the conclusion, Jody Kraus observes that "[a]ccording to Rawls, political liberalism cannot take any position on the defense of its own truth." Kraus, supra note 94, at 60.

117. Macedo, supra note 76, at 27.

118. Ernest Gellner explains that "[i]ndividualism, egalitarianism, freedom, sustained innovation - these traits are, in the comparative context of world history, unusual, not to say eccentric." ERNEST GELlnER, POSTMODERNISM, REASON AND RELIGION 52 (1992)

No wonder that Americans tend to treat these principles as universal and inherent in the human condition. The preamble to the American Declaration of Independence informs them that its truths are self-evident, and Americans tend to assume it to be so. But they are nothing of the kind: these assumptions are in fact heretical or unintelligible in most other cultures.

Id.; cf. Fletcher, In God's Image, supra note 61, at 1612-13 (citations omitted) ("Nothing quite like 'all men are created equal' is ever cited in the German jurisprudence of equality or, so far as I know, in any other legal culture of the world."). 
democracies or perhaps even, as Macedo says, of America. ${ }^{119}$

But this limitation negates the Enlightenment resolution to make reason independent of culture; it effectively turns reason into a complacent endorsement of the ideals and values of the culture that in our self-satisfaction we happen to inhabit. Indeed, proponents of the modern Enlightenment ideal may be quite frank in acknowledging that they simply have nothing to say-or no arguments to make - to people who do not already share their basic premises and commitments. ${ }^{120}$ For old-style partisans of a more hard edged reason like Ernest Gellner, this acceptance of culture as providing the grounds for judgment is simply disguised nihilism ${ }^{121}$ — hardly what the Enlightenment aspired to. In a similar vein, Vittorio Hosle sees in the modern tendency to present liberal commitments as simply those of a particular culture a "Nietzschean self-dissolution of enlightenment."122

Moreover, even if we are content to ground central political commitments in a merely local consensus, that consensus exists, if at all, only at the most abstract level — at the level of generalities like equality, reciprocity, fairness, and dignity. Modern partisans of Enlightenment depend on these concepts to do a great deal of work in justifying more specific decisions involving distributive justice or rights. But the concepts are at best very abstract; in some instances, such as equality and reciprocity, they are largely formal, and thus innocent of substantive content. ${ }^{123}$ Meanwhile the actual argumentative work and the particular

119. "The fact is that America does enjoy a widespread consensus ..." Macedo, supra note 76 , at 27.

120. See, e.g., RAWLS, Public Reason, supra note 70, at 132-33 (noting, with respect to those with a "zeal to embody the whole truth in politics," that "[p]olitical liberalism does not engage those who think in this way"). "They assert that the religiously true, or the philosophically true, overrides the politically reasonable. We simply say that such a doctrine is politically unreasonable. Within political liberalism nothing more need be said." Id. at 178.

121. See GELLNER, supra note 118 , at 49.

[Ian] Jarvie's simple and unanswerable point is that if all standards are an expression of culture (and cannot be anything else), then no sense whatever can be ascribed to criticizing cultures as a whole. No standards can then conceivably exist, in terms of which this could ever be done.... [Clifford] Geertz seems bizarrely blind to this genuine and fully justified fear ....

Id. Noting that Geertz denies being a nihilist, Gellner adds that the fact that the view that normative standards are relative to culture implies nihilism "does not mean that people must in fact, psychologically, also become nihilists if they are relativists. . . We cannot legislate against inconsistency, and have no wish to do so." Id. at 50.

122. VitTorio Hosle, OBJective IdEALISM, EThics, AND Politics 44 (1998).

123. The classic modern exposition is Peter Westen, The Empty Idea of Equality, 95 
conclusions in specific controversies demand more specific and substantive - and contested-premises. So how does a theorist - or a court - get from a very general and perhaps purely formal premise to a specific substantive conclusion without offending the consensus criterion that modern reason uses as a working principle?

The crude answer would be, as the old farmer told the lost tourist, "You cain't get there from here." But the practical questions of life demand answers, so answers will somehow be forthcoming; and the standard rhetorical moves that serve to deliver those answers have become familiar. One tactic is to invoke a generic concept such as equality, while tacitly importing a more specific substantive conception that would be controversial if openly stated. ${ }^{124}$ Criticizing Rawls's position, for example, Michael Zuckert argues that although there may be a cultural consensus favoring the concept of equality, "there is also a wide range of disagreement over what about persons makes them equal, and over what the claim of equality entitles them to." 125 But "when Rawls brings the agreement on the concept of equality into his system he treats it as if it were an agreement on a conception." ${ }^{26}$ No such agreement exists, however, so the "shift from concept to conception is simply arbitrary and illegitimate within the terms of Rawls's own thought." 127

A different but equally familiar strategy is to gerrymander the constituency so as to eliminate dissenters who might disturb the necessary consensus. Reason, as noted, speaks only to "reasonable" people, so those who inconveniently disagree with a necessary proposition can easily be placed outside the boundaries by being declared "unreasonable." In this vein, the writings of theorists like Rawls, Macedo, Gutmann, and Thompson teem with pronouncements declaring what reasonable people believe, and disfellowshipping dissenters from the congregation of the reasonable.

For those who inhabit the cultural neighborhood of Rawls, Macedo, and Gutmann, the exclusionary implications of public reason or democratic deliberation may be easy to overlook, or at least to excuse. The claims of public reason will seem almost truistic; and Rawls, Macedo, Dworkin, and associated representatives of the modern Enlightenment will appear to be the personification of sweet reasonableness.

HARV. L. REV. 537 (1982).

124. I discuss this rhetorical strategy in the religion clause context at greater length in Steven D. Smith, GetTing Over Equality: A Critical Diagnosis of Religious FREEDOM IN AMERICA 13-20 (2001).

125. Zuckert, supra note 68 , at 77.

126. Id. at 78 (emphasis added).

127. Id. 
Conversely, to those who dwell in other neighborhoods - even within the broad community called "America" - the confident claims of these enlightened thinkers will seem smug, incredible, and almost inexplicable. Thus, perplexed at the spectacle of "[1]iberal ideologues, who celebrate tolerance and pluralism while at the same time condemning any meaningful dissent from their own thin idea of the good as not merely wrong but contrary to the dictates of reason itself," Paul Campos is reduced to speculating that Rawlsian claims about reasonableness and the overlapping consensus can enjoy plausibility only among a select group of academicians whose world is effectively limited to those who "work at the same institutions, attend the same conferences, read the same newspapers, live in the same suburbs, and send their children to the same schools." $" 128$

In a similar vein, Stanley Fish painstakingly shows how a variety of prominent liberal thinkers, always respectful of "Enlightenment decorums," effectively "elevat[e] the decorum of academic dinner parties to the status of discourse universals." 129 Fish argues that when theorists like Gutmann and Thompson talk about reason and reasonableness, in reality

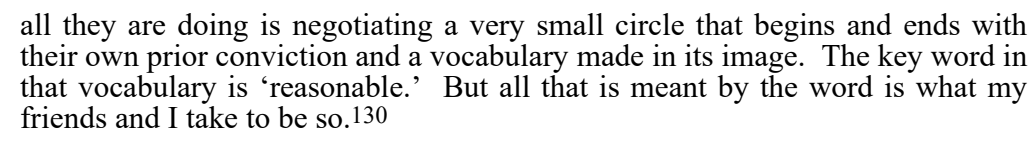

all they are doing is negotiating a very small circle that begins and ends with their own prior conviction and a vocabulary made in its image. The key word in that vocabulary is 'reasonable.' But all that is meant by the word is what my friends and I take to be so. 130

Proponents of public reason will answer, of course, that Fish's characterization is unfair: citizens are classified as unreasonable not because the theorists disagree with their substantive opinions but rather because these citizens misunderstand or disrespect something like the principle of reciprocity. ${ }^{131}$ But this criterion, upon closer inspection, turns out to add nothing to the judgment that a person or view is unreasonable. After all, reciprocity, like equality, is in itself a formal principle; it gets "bite" only when filled with particular substantive content. Reciprocity can be extended or denied, that is, on the basis of all sorts of substantive terms: it is as much a manifestation of reciprocity

128. CAMPOS, supra note 58, at 191, 201-02.

129. Stanley Fish, The Trouble With Principle 194, 68 (1999).

130. Id. at 195; $c f$. OWEN, supra note 90 , at 113 ("[T] he capacity of people to come to an agreement despite their supposedly profound differences is not so amazing, since Rawls has from the outset included as parties to the discussion only those liberals who do not differ on the crucial political question at issue.").

131. See, e.g., RAWLS, PL, supra note 70, at 49-50. 
to let everyone participate in the discussion so long as they accept a generally theistic framework - basically the eighteenth century view - as it is to let everyone participate in the discussion so long as they do not employ a theistic framework, which is roughly the view taken by many secular liberals today. Thus, no one need have any quarrel with the idea of reciprocity in itself. And indeed, where are the scholars or citizens who proclaim themselves opposed to reciprocity as a value? In reality, disputes are always about what substance to pour into that congenial vessel, and the accusation that some person or group is unwilling to accept the criterion of reciprocity will virtually always be a veiled way of saying that the accused is unwilling to accept the substantive terms that the accuser would want to be (reciprocally) respected.

More specifically, the modern partisans of Enlightenment want reciprocity on what they deem reasonable terms. But in this way we end up with a circularity: a person is said to be unreasonable because he disrespects the requirement of reciprocity, but to say that he disrespects the requirement of reciprocity turns out to be just a way of saying that he is not being reasonable. Hence, reciprocity adds nothing (except beguiling packaging) to the judgment of reasonableness.

To be sure, partisans of the modern Enlightenment may argue that in excluding unreasonable persons and views from disturbing the overlapping consensus, they are merely invoking a legitimate and necessary qualification-and one that Enlightenment thinkers have always invoked. It is true-isn't it? - that the process and products of reason will be recognizable only to reasonable people? Moreover, even during the historical Enlightenment, ostensible appeals to consensus-or to the judgment of all mankind (as in the Declaration of Independence) - were tacitly understood to be much more limited in their intended audience: reason was, as noted, mostly a pastime for "gentlemen of generous education and large views." 132 Nonetheless, two important differences separate the modern invocation of seemingly spurious consensuses from the eighteenth-century practice.

First, the exclusion of persons from the "reasonableness" category seems more conspicuous today-and more conspicuously arbitrary. In the eighteenth century, the class of "gentlemen of generous education" might well have been at least roughly coextensive with the class of people who enjoyed the franchise and a significant degree of literacy. Today, by contrast, the masses of people excluded for various purposes from the category of the reasonable would encompass thousands or even millions of citizens who function successfully in life (often in professions requiring intelligence and training), who have some education, even

132. MAY, Divided HeART, supra note 10, at 155. 
considerable education, and who are eligible to vote and hold public office. ${ }^{133}$ In this context, it is hard to understand the label "unreasonable" to mean anything other than "in unacceptable disagreement with me."

Second, the function of consensus in modern thinking is in fact quite different than it was for the classical Enlightenment-and thus not amenable to the same sorts of restrictions. In the seventeenth and eighteenth centuries, as discussed, consensus was a criterion of and a means to truth-much as the requirement of mutual verifiability continues to be in science. If a proposition is true, it was supposed, then through reason all competent and honest people should in principle be able to apprehend its truth. And a moral or political proposition could be true, or false, because there was thought to be a Truth, or a "Nature," that the proposition could correctly or incorrectly represent - in the same way that a proposition in physics or chemistry (about the movements of particles, or about cold fusion) can be true or false because there is a material reality that the proposition may or may not represent correctly. Thus, if for Jefferson '[t $\mathrm{t}$ he word 'right' was always a signpost pointing back to the divine plan of the Creation," 134 a proposition about rights would be true if it correctly represented that plan-false if it did not. On this understanding, it made sense - in principle, anyway - to count the opinions of those who might have some presumptive competence to grasp the objective Truth or Nature that was at issue, and to disregard the opinions of anyone who lacked such ability.

By contrast, in modern Enlightenment thought, consensus serves no similar function. Though modern partisans of Enlightenment may eschew the label of relativist and claim to believe in moral objectivity, their descriptions of the nature of that objectivity tend to be excruciatingly coy. Moral judgments may be said to be objectively true in some elusive sense, but they are surely not taken to be reports about anything "out there," or about "the fabric of the moral universe," 135 in

133. For example, Rawls's famous abortion footnote, in which he peremptorily pronounces "to that extent unreasonable" any doctrine (and presumably any person embracing such a doctrine) that would restrict abortion beyond approximately the trimester framework of Roe v. Wade, would surely exclude millions of Americans for purposes of that issue. See RAwLS, PL, supra note 70, at 243 n.32. For some less than lucid (to me, at least) backtracking, see RAwLS, Public Reason, supra note 70, at 169 n. 80 .

134. BOORSTIN, supra note 58, at 194.

135. See Ronald Dworkin, Objectivity and Truth: You'd Better Believe It, 25 PHIL. \& Pub. AfF. 87, 99, 105 (1996). 
the way they were for the eighteenth century. So it is not clear just what sort of objective reality or Truth a moral or political-moral claim would be about, or would represent. And indeed, as noticed already, contemporary theorists describe the value of consensus not in terms of a test of truth, but rather in terms of political and social values such as fairness, civility, and cooperation.

But when consensus is understood in this light, then the eighteenthcentury justification for regarding the opinions of a select class disappears. Conversely, those whose opinions do not count are excluded not because they lack the capacity to perceive the Truth-which in any case is not a proper subject for public discourse-but rather, more directly and bluntly, because their opinions fall outside the overlapping consensus on which the excluders would prefer to build their political community.

It is as if a group calling itself the "Astronomy Society" gradually lost all interest in the stars but continued, largely for social or solidarity purposes, to hold conventions to collect and admire old telescopes that they find aesthetically appealing; and the group excludes particular telescopes (and their owners) from these conferences not because the telescopes do not work, but because they are aesthetically unappealing. In short, telescopes continue to serve a function, but it is nothing like the same function for which they were originally developed; consequently, the rationale and criteria for approving some telescopes and disapproving others are wholly different than those that initially guided the society. By the same token, consensus is prized in contemporary liberal thought for its political, not its philosophical or epistemic value. In this context, to say that a person, or moral or philosophical view, will not be counted because the person or view is "unreasonable" is tantamount to saying not that the person lacks some epistemic capacity or that the view is false-False relative to what? What would that judgment even mean? - but rather that the person or view is offensive to the group that is running the discussion. In this way, the modern Enlightenment lapses into a sort of high-toned neo-tribalism.

The inversion of freedom of expression. The classical Enlightenment, as we noticed earlier, was inclined to be friendly to the idea of freedom of expression. The modern Enlightenment is more ambiguous on this point. On the one hand, modern partisans of Enlightenment maintain the legacy of opposition to familiar or conventional forms of censorship. ${ }^{136}$ Not only is such opposition a prominent part of the Enlightenment

136. Rawls, for example, rehearses and reaffirms the standard received doctrines and decisions protecting freedom of speech and press. RAWLS, PL, supra note 70, at 340-56. 
legacy; the modern heirs of that legacy may sense that traditional censorship is based on moralistic or religious rationales that should be relegated to the private sphere in any case. So it is natural for proponents of the modern ideal to favor freedom of expression in these familiar contexts. ${ }^{137}$

In a less overt but arguably more important way, however, the modern Enlightenment has a strongly censorial cast. We have already noticed how the modern ideal of public reason attempts in varying degrees to cleanse public discourse of the explicit invocation of religion or other comprehensive views. Critics of such restrictions plausibly see them as an effort to suppress expression-and in the area that has typically been regarded as the core First Amendment concern (that is, political speech). The public reason of the modern Enlightenment thus stands as a censor looming over public discussion.

Consider, for example, Rawls's analysis of the vexed issues of sexual conduct and same-sex marriage. ${ }^{138}$ In popular, public, and academic debate, these issues currently generate wide-ranging discussion addressing a broad spectrum of legal, moral, psychological, sociological, and even theological concerns. But in a debate governed by the constraints of public reason, much of this discussion would be ruled out of bounds. "[T]he government would appear to have no interest in the particular form of family life, or of relations among the sexes," Rawls matter-of-factly remarks, "except insofar as that form or those relations in some way affect the orderly reproduction of society over time."139 Much of what people currently argue about and, it seems, care about, is accordingly decreed irrelevant to legal and political concerns. In particular, many of the familiar arguments that appeal to moral values or religious convictions would be deemed inadmissible, not because the arguments are false - as to that public reason has nothing to say-but because they "reflect religious or comprehensive moral doctrines." 140

137. In newer, less familiar contexts, the inheritance may speak less clearly, and may also pose conflicts between expression and other Enlightened values such as equality. Hence, issues involving, for instance, "hate speech" or pornography that arguably promotes the subordination of women may leave the partisans of Enlightenment uncertain and divided.

138. RAWLS, Public Reason, supra note 70, at 147.

139. Id.

140. Id. Rawls allows, though, that other values beyond the reproduction of society might be admissible for consideration, including "the equality of women" and the needs of children. Id. 
The discussion thus becomes much simpler and the proper conclusions far easier to reach: that is because much of the current debate has been censored to meet the standards of public reason.

To be sure, liberal theorists usually do not extend the constraints of public reason to all public discussion (though if public reason could actually work as advertised it is puzzling why its beneficent jurisdiction should be confined). Rawls, for instance, insists that decisions be made on the basis of public reason only with regard to "constitutional essentials and questions of basic justice"; ${ }^{141}$ he is ambivalent about extending similar constraints to less vital political issues. ${ }^{142}$ Not surprisingly (but perhaps ironically), Rawls's supporters tend to emphasize the very limited coverage of the idea of public reason. ${ }^{143}$ Even where the constraints are in force, moreover, Rawls would not necessarily forbid the expression of views that do not meet the demands of public reason: citizens would be permitted (and sometimes even encouraged) to air their nonconforming views so long as-Rawls calls this "the proviso"- "in due course public reasons... are presented sufficient to support whatever the comprehensive doctrines are introduced to support." 144 These indulgences do little to moderate the censorial force of public reason: they amount to telling citizens that on the most important public issues it is permissible to express views about religion, or Truth, only on the condition that the final decision does not depend on those views - which seems tantamount to saying that people can express their nonconforming views so long as those views make no difference to the actual outcome of the debate. ${ }^{145}$

141. RAWLS, PL, supra note 70, at 215.

142. Compare RAWLS, Public Reason, supra note 70, at 134 ("The idea of public reason does not apply to the background culture with its many forms of non-public reason nor to media of any kind.") with RAWLS, PL, supra note 70, at 215.

$[\mathrm{M}] \mathrm{y}$ aim is to consider first the strongest case where the political questions concern the most fundamental matters. ... Should [the limits of public reason] hold here, we can then proceed to other cases. Still, I grant that it is usually highly desirable to settle political questions by invoking the values of public Id. reason.

143. See, e.g., Philip L. Quinn, Religious Citizens Within the Limits of Public Reason, 78 THE MOD. SCHOOLMAN 105, 107, 117 (2001).

144. RAWLS, PL, supra note 70, at li-lii.

145. I acknowledge, however, that Rawls's explanation on this point seems less than clear, and hence might be interpreted more leniently. For example, the requirement that a nonconforming argument be supported by "public reasons" that are "sufficient" conceivably might be understood to impose only something like constitutional law's traditional, very minimal "rational basis" requirement; in that case, both the restrictiveness and the significance of the "public reason" ideal would be drastically diluted. There seems no way to know. Cf. RAWLS, Public Reason, supra note 70, at 153 ("Yet the details about how to satisfy this proviso must be worked out in practice and cannot feasibly be governed by a clear family of rules given in advance."). 
Indeed, Rawls himself concedes that if the constraints of public reason were legally enforced they would be "incompatible with freedom of speech." $146 \mathrm{He}$ attempts to deflect concern by explaining that the constraints will be backed only by a "moral duty."147 As John Stuart Mill emphasized, however, social or cultural constraints can be as inhibiting to freedom of expression as legal restrictions are; ${ }^{148}$ and the modern partisans of Enlightenment ardently cultivate those kinds of constraints. ${ }^{149}$ Moreover, it is misleading to suggest that the censorship promoted by the modern Enlightenment ideal is not legally enforced. The legal sanction typically consists not of criminal punishment, but rather of judicial invalidation of measures thought to have been adopted on the basis of nonconforming grounds. As we have seen, that sort of sanction is very much (if very haphazardly) in force-most obviously in the establishment clause context. Citizens who would introduce disfavored rationales into public debate are put on notice, in effect, that by doing so they risk invalidation of the measures they favor.

More generally, the modern institution of judicial review based on the assumption that laws and government actions are valid only if based on, and defensible in terms of, secular and instrumental justifications is itself a sort of overweening censor over public deliberation. Robert Nagel has explored this aspect of modern constitutionalism. The rationalism of modern constitutional law "tends to denigrate important values and to

146. Rawls, Public Reason, supra note 70, at 136. 120.

147. Id. Once again, supporters emphasize this limit. See Quinn, supra note 143, at

148. Protection ... against the tyranny of the magistrate is not enough; there needs protection also against the tyranny of the prevailing opinion and feeling, against the tendency of society to impose, by other means than civil penalties, its own ideas and practices as rules of conduct on those who dissent from them; to fetter the development and, if possible, prevent the formation of any individuality not in harmony with its ways, and compel all characters to fashion themselves upon the model of its own.

John StUART MiLl, On LiberTy 7 (Currin V. Shields ed., 1956) (1859).

149. For instance, Rawls calls for the inculcation of an "ideal" of public reason-he distinguishes this from the "idea" of public reason - in citizens, who will be encouraged to think of themselves "as if" they were legislators subject to the constraints of public reason. RAWLS, Public Reason, supra note 70, at 135. Jeffrie Murphy points out that in the Rawlsian scheme, citizens who resist the constraints of public reason "are not to be coerced, but they are legitimately to be criticized - perhaps even made to feel bad or shunned-in short, to be made the object of social but not legal pressure." Jeffrie G. Murphy, Religious Conviction and Political Advocacy (A Commentary on Quinn), 78 THE MOD. SCHOOLMAN 125, 127 (2001). 
stunt moral and political discourse," Nagel argues. ${ }^{150}$ In particular, "courts often operate under the assumption that beliefs that originate in tradition ... are impermissible bases for public policy, unless they can be justified by some rational standard extrinsic to the tradition."151 Consequently, "the felt interests of those who hold affection for tradition are systematically (although, of course, not always) slighted."152 And the prevailing rationalism tends to discount and filter out the views of those constituencies, arguably comprising much of society, that are not given to formulating rationalist or theoretical articulations of their beliefs. ${ }^{153}$

More specifically, Nagel painstakingly explains how the Supreme Court has directly either acted as a censor or supported other government censors in areas such as sex-specific advertising, abortion, and racial integration: "not only does the Supreme Court sometimes permit agencies to censor information for purposes of mind control but also in important areas the Court itself acts as the censor." 154 And in a subtle but pervasive way, he argues, the very proclivity of Americans to look to courts for the resolution of so many difficult controversies - and the willingness of courts to provide and impose such resolutions - reflects a sort of self-censorial impulse.

[T] $]$ he Court not only occasionally exemplifies our inclinations toward mind control but also in a larger sense embodies our need to escape ourselves. The degree to which in modern times we increasingly and unshakably are dependent on this institution is a sign of how much we want to censor ourselves. ${ }^{155}$

In sum, the modern Enlightenment for the most part retains the specific inherited commitments to freedom of expression; but its more vital impulse, most clearly reflected in its descriptions of public reason in terms of large bodies of belief that should be discouraged or excluded from public discourse, has a strongly censorial character. And this censorial bent is entirely consonant with the central logic of the modern Enlightenment. The classical Enlightenment, as we have seen, was motivated by a desire to live in accordance with Truth and by a confidence (perhaps reflecting the prevailing providential worldview) that discussion would naturally lead human beings in the direction of Truth. Having effectively abandoned those premises and reoriented the political task toward civility and cooperation, the modern Enlightenment

150. NAGEL, supra note 98 , at 111-12.

151. Id. at $116-17$.

152. Id. at 117 .

153. Robert F. Nagel, Judicial Power and American Character 151-54

154. Id. at 110. See generally id. at 103-21.

155. Id. at $143-44$. 
has little reason to be enthused about the specific practical commitment to free expression.

There is nothing surprising about this conclusion. Children have long been taught that it is bad manners to talk about religion or other potentially controversial subjects in certain kinds of society. Where the goal is cooperation and civil peace, potentially inflammatory subjects are best left alone: People who breach this etiquette are silenced by being ignored, frowned at, and not invited back. The modern Enlightenment ideal of public reason represents the political elaboration of this conventional - and censorial-wisdom.

The exhaustion of Enlightenment culture? Starting out as an effort to break free of culture and tradition, the Enlightenment has itself become a tradition: thus, scholars talk easily of "Enlightenment culture" or "the Enlightenment tradition."156 Though this development might be thought to constitute a self-contradiction, the development was also unavoidable; and it would be harsh to take the modern Enlightenment too much to task for succumbing to the inevitable. As noted earlier, it seems more charitable to interpret the classic distinction between reason and culture not as asserting a strong and philosophical (but also untenable) dichotomy, but rather as expressing a sense that the particular culture within which Descartes and his successors lived had become exhausted and inauthentic - unable to support genuine, meaningful discourse or to command sincere assent. In the culture in which a founder of the Enlightenment such as Descartes lived, most people were no doubt working away in relative content: lawyers and scholars and theologians and politicians were writing, debating, expounding, drawing conclusions - just as their descendants are today. At the same time, it seems there must have been an underlying sense, felt by some, that the discourse was not working as it should, or as it once had. As discussed, Stephen Toulmin has described the easy-going, moderately skeptical mindset of the period that many may have found attractive - and that Toulmin himself recommends-but that was deeply unsatisfying to someone like Descartes, with his pressing demand for truth.

156. See, e.g., Thomas Fleiner, Comparative Constitutional and Administrative Law, 75 TUL. L. REV. 929, 939 (2001) (referring to "enlightenment culture"); Rosemary J. Coombe, Critical Cultural Legal Studies, 10 Yale J.L. \& Human. 463, 471 (1998) (referring to "Enlightenment traditions"); Suzanna Sherry, All the Supreme Court Really Needs to Know It Learned from the Warren Court, 50 VAND. L. REV. 459, 481 (1997) (referring to "the Enlightenment tradition"). 
Does the culture of today in which lawyers and scholars - and citizens - live display similar characteristics of exhaustion? ${ }^{157}$ We can see in the public discourse advocated by modern partisans of Enlightenment a sort of degenerative dynamic that seems constituted to render that discourse incapable of speaking to us on any deep level or in any convincing way.

Start with John Coleman's observation that "[s]ecular Enlightenment language remains exceedingly 'thin' as a symbol system." 158 This "thin" quality is not accidental, but rather deliberate; it would be only a slight exaggeration to say that Enlightenment discourse aspires to thinness. As discussed above, Enlightenment reason adopts consensus as a working or operational principle: only premises, beliefs, and modes of argument and inference generally accepted by reasonable persons independent of personal idiosyncrasies or cultural particularities can qualify for the label of "reason." As a community becomes increasingly pluralistic, the Enlightenment conception of reason necessarily excludes more and more, and the material available for reasoning accordingly becomes increasingly meager.

As the material available for argument and justification becomes scantier, however, a worrisome prospect appears: What if the discursive resources available within the domain of secular public reason are insufficient to resolve a difficult issue, or to provide a satisfying justification for a decision on such an issue? This worry is hardly academic. On the contrary, it seems almost inevitable that at least for highly controversial issues - abortion is only the most obvious - the limited resources of public reason in a radically pluralistic society will be incapable of providing a persuasive basis for decision and justification. ${ }^{159}$

157. For a diagnosis of this situation in law, see Steven D. SMith, LAw's QUANDARY (forthcoming 2004).

158. John A. Coleman, An American Strategic Theology 193 (1982). It is a symptom of this "thinness," I think, that even secular theorists sometimes resort to a religious vocabulary in order to convey their most profound commitments. For instance, Ronald Dworkin makes pervasive use of the language of the "sacred" in trying to explain the value of human life. RONALD DwORKIN, LifE's DOMINION 68-101 (1994). But, as Michael Perry argues, Dworkin cannot give any satisfying secular account vindicating this usage; rather, it seems that Dworkin is "trading on the greater strength of the objective sense in which the word is ordinarily used" in order to underscore a commitment that a secular vocabulary is too weak to convey. PERRY, supra note 100, at 25-29. See also Pojman, supra note 101, at 287 ("[O]ne must wonder at the sacerdotal language used [by Gregory Vlastos] of human beings: 'sacred,' of 'infinite value,' 'inviolability,' and so forth. The religious tone is not accidental, but the lack of reference to religion is a serious omission.").

159. Rawls attempts to avoid this problem by stipulating that an "essential feature of public reason is that its political conceptions should be complete," meaning that it is adequate to "give a reasonable answer to all, or to nearly all, questions involving constitutional essentials and matters of basic justice." RAWLS, Public Reason, supra note 
In this predicament, the community would face an unappealing set of alternatives. Lacking any adequate basis in reason to make a decision, the community might simply be paralyzed - unable to decide or act. Or, more realistically, the community might make a decision anyway-by smuggling in considerations that do not enjoy the support of any consensus and that cannot plausibly be presented as part of a justification limited to public reason. Rawls purports to forbid this course, but instead suggests that "when there seems to be a stand-off, that is, when ... arguments seem evenly balanced on both sides, ... citizens must vote for the ordering of political values they sincerely think the most reasonable."160 So put, this imperative is akin to a recommendation that says that if you have to choose between what look to be two equally sized pieces of pie, pick the piece that looks bigger.

Realistically, therefore, smuggling is inevitable. And we can readily imagine the consequences. As such smuggling becomes a common practice, it will be hard to conceal from the active, street-wise participants in the discourse. They will come to understand that public debate often does not explicitly set forth the real reasons that in fact motivate the parties to the debate, and that public justifications often fail to present the considerations that in reality determined the decisions for which the justifications are being offered. Everyone is keeping his or her cards hidden, so to speak. Thus, a climate of suspicion will come to pervade the discourse. Moreover, the more generic reasons given for a decision will often be so palpably unpersuasive that it will be natural for those who oppose a particular decision to regard the justification as spurious and disingenuous - as virtually no justification at all. The decision will thus come to have a "because I said so" quality. In this way, what began as (and what may still advertise itself as) an enterprise in governance on the basis of reasoning from and toward mutually acceptable commitments will become - or at least will appear to many of those affected to be- the disingenuous exercise of raw power. ${ }^{161}$

We can appreciate this dynamic by reference to one of the most

70, at 144-45. A discourse lacking such completeness, it seems, would not qualify as a form of public reason. This stipulation does nothing to address the problem, however, but merely prompts a reformulation of the objection: not "[p]ublic reason will leave many questions unanswered," but rather "[p]ublic reason (so defined) does not exist."

160. RAWLS, Public Reason, supra note 70, at 168 (emphasis added).

161. Cf. Alasdair MacInTyRe, After VirTue 71 (2d ed. 1984) (describing modern moral discourse as "a rhetoric which serves to conceal behind the masks of morality what are in fact the preferences of arbitrary will and desire"). 
thoughtful and balanced treatments of public discourse. Kent Greenawalt's work on the subject is characterized both by a commitment to public reason and liberal constitutional values and by an appreciation of the importance of religion in the lives of many citizens. ${ }^{162}$ In an early book on the subject, he astutely pointed out that the complacent assumption that all citizens ought to be able to bracket their religious convictions and deliberate for public purposes on rational, secular grounds misconceives the way religion works in the lives of many citizens. And he showed that at least some important issues cannot be settled purely on the basis of rational or "publicly accessible" grounds. ${ }^{163}$ Greenawalt has consistently sought a moderate or compromise position which would not exclude religious citizens from participation in public life but which would also adhere to the ideal of a nonsectarian and generally accessible public reason.

In his effort to find such a middle ground, Greenawalt has argued that in many contexts it is appropriate for participants to rely on their religious convictions in making political decisions but that these convictions should not be openly expressed in public discussion or justification. Instead, the arguments or justifications should be presented in more generic terms: not "God requires... ," but rather "The public good is best served by ...." This translation of religious beliefs into the secular language of public reason will be less offensive to nonbelievers, and Greenawalt argues-persuasively - that the translation is not dishonest; it is only less revealing of the full reasons for the position taken. Incomplete disclosure is not equivalent to misrepresentation. ${ }^{164}$

There are surely contexts in which the strategy recommended by Greenawalt is appropriate, perhaps even ethically required. ${ }^{165}$ Notice, though, that incomplete disclosure has its own costs, which may be debilitating over the course of time. Suppose that on difficult issues and for the laudable purposes that influence Greenawalt, I routinely provide you with generic justifications for my positions-justifications that, though honest as far as they go, deliberately decline to reveal the deeper reasons for my views and actions. And suppose you do the same with me. Over time we will surely come to understand that we are both engaged in this common practice. What will this understanding do to

162. See generally Kent Greenawalt, Religious Convictions and Political CHOICE (1988).

163. Id.

164. See, e.g., Kent Greenawalt, Private Consciences and Public Reasons 137-40, 163-64 (1995).

165. I have discussed this point (and Greenawalt's effort to find a moderate position) at greater length, and favorably, in Steven D. Smith, Augustinian Liberal, 74 Notre DAmE L. ReV. 1673 (1999). 
the quality of our mutual conversation?

Well, in the first place, our discussion can hardly be a very profound or satisfactory exercise of reason. How could it be, when the decisive grounds for our views and actions are not exposed for examination? We will be engaged more in trading conclusions-or at best mid-level and largely conclusory premises - than in examining our deepest convictions and commitments. Further, while our generic strategy may help us to "just get along" in the short run, it is unlikely to lead to any deep rapport or mutual understanding. So long as we stick to this strategy, we will not really get to know each other.

Worse than that, our strategy is likely to breed mutual suspicion. You tell me that you favor political decision X for (generic) reason Y, but I understand that you are not disclosing what is actually the decisive consideration - and that if you did, I would almost surely not accept it. (You understand that I would not accept it, and I understand that you understand this; otherwise you would have incentive to disclose it, and no reason not to disclose it). For all I know, your generic reason may be concealing - from me, and perhaps from yourself as well-what is actually a self-serving motive. It may well be that in purporting to give me reasons, you are in reality merely trying to manipulate me-to exercise power over me. The pretense of reason may be merely an exercise of the "will to power."

I have been speaking speculatively and hypothetically of a dynamic whereby the modern Enlightenment conception of reason and the kind of discussion it prescribes might deteriorate into a thin discourse of suspicion, manipulation, and willfulness. Does this hypothetical description have any application to the public discourse, and in particular the constitutional discourse, that prevails in the United States today? The evidence is overwhelming that it does, I think, but for present purposes I will merely cite as examples two respected constitutional scholars, who speak with specific reference to the justifications given in constitutional decisions. H. Jefferson Powell contends that American constitutional discourse is "incoherent rationally" and hence is not so much an expression of reason as a manifestation of "violence [that] is increasingly wayward, increasingly brutal."166 "[C]onstitutionalism," Powell asserts, "is one of the most seductive masks worn by state

166. H. JEFFERSON POWELl, The MORAL TRAdition OF AMERICAN CONSTITUTIONALISM $262(1993)$. 
violence."167 More recently, Anthony Amsterdam (along with many other critics, of course) caustically condemns the Supreme Court's decision in Bush v. Gore, ${ }^{168}$ calling it an instance of "sickening hypocrisy and insincere constitutional posturing"; but the decision, Amsterdam goes on, is not distinctive but merely especially brazen in these respects. ${ }^{169}$ "[T] he court finally has revealed unmistakably what it does all the time and usually gets away with: masking result-driven, political, unprincipled decisions in the guise of obedience to rules of law which the justices feel completely free to twist and retwist to suit their purposes." 170

These pronouncements may seem hyperbolic or even, in Amsterdam's case, almost hysterical. But if the analysis given earlier is correct, the suspicion these statements exude is precisely the attitude that the degenerative dynamic of Enlightenment discourse - of public reason-seems destined to produce.

The problem was diagnosed almost half a century ago by John Courtney Murray. "As we discourse on public affairs," Murray argued, "on the affairs of the commonwealth ... we inevitably have to move upward, as it were, into realms of some theoretical generality-into metaphysics, ethics, theology." 171 But of course these are precisely the realms that the modern Enlightenment, as exemplified by thinkers like Rawls, excludes from the jurisdiction of public reason-because no overlapping consensus is likely to obtain there. The result, however, is not a genuine consensus, but simply an impoverishment of the public domain. In the public conversation fostered by the modern Enlightenment, Murray perceived "a climate of doubt and bewilderment in which clarity about the larger aims of life is dimmed and the self-confidence of the people is destroyed, so that finally what you have is ... impotent nihilism."172 The irony is that this loss of content is not in fact compensated for by any gain in genuine consensus or civility.

The fact is that among us civility — or civic unity or civic amity, as you will—is a thing of the surface. It is quite easy to break through it. . . .

$\cdots$

... There is not simply an exchange of arguments but of verbal blows. You do not have to probe deeply beneath the surface of civic amity to uncover the structure of passion and war. 173

167. Id. at 47 .

168. 531 U.S. 98 (2000).

169. Anthony G. Amsterdam, The Law Is Left Slowly Twisting in the Wind, L.A.

TIMES, Dec. 17, 2000, at M5.

170. Id.

171. See, e.g., MurRAY, supra note 13, at 15.

172. Id. at 12 .

173. Id. at $18-19$. 


\section{RENEWING THE ENLIGHTENMENT?}

The preceding discussion has suggested that although the modern Enlightenment retains-rhetorically, at least - a commitment to governance in accordance with reason, this commitment has been transformed into almost the opposite of what it meant in the period leading up to and including the American founding. The eighteenthcentury providential worldview that furnished the framework for reasoning has been abandoned, at least for purposes of public and academic discourse. The imperative to live according to Truth has been radically amended to become an admonition against bringing Truth into public discourse. And the predictable result has been the development of a public discourse that seems increasingly exhausted and inauthentic - unable to address our real questions and concerns or to generate genuine conviction. ${ }^{174}$ In short, modern Enlightenment culture seems very much like the complacent, moderate, skeptical culture against which the classical Enlightenment rebelled. And it appears to suffer from the very condition that, according to Stephen Toulmin, provoked the development of the Enlightenment project by thinkers such as Descartes - a "crisis of belief." 175

So the question arises: Might we not be in need of a new Enlightenment - one that would challenge the current intellectual culture in the same way that the classical Enlightenment challenged the culture it inherited from the Middle Ages and early modernity? Is the modern Enlightenment ideal - an ideal promoted in various forms by so many mainstream thinkers and scholars - ripe to be enlightened by a renewed commitment to finding and living by truth, or by Truth?

Perhaps, but there are difficulties. Most obviously, it is difficult to

174. Cf. Morton J. Horwitz, Foreword: The Constitution of Change: Legal Fundamentality Without Fundamentalism, 107 HARV. L. REV. 30, 40 (1993-94) (observing a "crisis of legitimacy in constitutional thought in which the generally accepted paradigms and modes of thought are no longer felt capable of yielding convincing solutions to constitutional questions"). For a collection of similar judgments by scholars from across the political and jurisprudential spectrum, see SMITH, REASON, supra note 9, at $125-26$.

175. Toulmin, supra note 21, at 45. For recent expressions of this assessment of contemporary culture, see Huston Smith, Why RELigion Matters: The FATE of THE Human Spirit in an Age of Disbelief (2001); Gregg Easterbrook, Beside Still WATERS: SeArching FOR MEANING IN AN AgE OF DoubT (1998). I have argued elsewhere that American legal thought over the last century presents a scene of jurisprudential stagnation reflecting a similar crisis in belief. Steven D. Smith, Believing Like a Lawyer, 40 B.C. L. REV. 1041, 1043-47 (1999). 
know where the course of trying to live by Truth would lead us today. Would we end up with "natural law," perhaps, or with the naked nihilism of a brutally honest Social Darwinism? With Plato, or with Thrasymachus? Fear of the something like the latter alternative is perhaps the principal bulwark sustaining the modern Enlightenment ideal even though it is no longer the carrier of belief and hope that it was two centuries ago.

In addition, the parallel to the origins of the historical Enlightenment is inexact. To be sure, the culture of modern liberal democracy bears many resemblances to the complacent, moderately skeptical intellectual culture of the late sixteenth century against which, at least in Toulmin's interpretation, the historical Enlightenment was a reaction. But that reaction, Toulmin says, grew out of more than intellectual dissatisfaction with a prevailing nonchalant attitude towards truth: the prevalent attitude was associated as well with social breakdown, and in particular with an inability to curb the destruction being wrought by religious warfare. Today, by contrast, America enjoys relatively high levels of material prosperity and an absence of conspicuous religious or social strife. There is, to be sure, a "culture war" that implicates the passionate concerns of many Americans ${ }^{176}$ still, that struggle is not at this point a source of massive violence and destruction in the way the wars over religion were in the sixteenth and seventeenth centuries.

In short, conditions in America (and in particular for the academic elite, at least in their material circumstances) are relatively comfortable at the moment, ${ }^{177}$ and comfort is compatible with complacency-towards, among other things, concerns such as "truth." Mill notwithstanding, it is usually easier, if less heroic, to be a pig satisfied than Socrates dissatisfied.

To be sure, the present comfortableness may be thin and also transitory. Some observers see in our current situation signs of moral and cultural decay. ${ }^{178}$ In a similar vein, Robert Nagel senses just below the cheerful surface of American culture "a brooding fear of potential disaster," and he sees the modern dependence on judicial review as a "recurring manifestation of . . . self-doubt." ${ }^{\text {179 }} \mathrm{He}$ may be right. But as

176. See James Davison Hunter, Culture Wars: The Struggle to Define AMERICA (1991).

177. This conclusion was written before September 11, 2001. I think it is too early to tell whether the description needs to be changed in light of more recent events.

178. See, e.g., Gertrude Himmelfarb, The De-Moralization of Society 221-57 (1995) (asserting that statistics indicate a downward moral and social trend that bodes even worse for the future than for the present); HoSLE, supra note 122, at 41 (asserting that "we are manifestly living in a time of moral, political, artistic, and intellectual decay").

179. NAGEL, supra note 153 , at $142,156$. 
Nagel himself argues, this anxiety has in recent decades prompted not honest self-scrutiny or an effort to rethink or return to fundamental truths, but rather a pattern of denial: more energetic "self-deception in a culture already afraid that it is too dependent on euphemism and evasion." 180

There is a second and perhaps even more important gap in the historical parallel. The intellectual culture of the late Middle Ages and early modernity was strikingly unlike modern Enlightenment culture in at least one crucial respect: it never renounced a concern for truth. On the contrary, the intellectual achievements of the Middle Ages grew out of a massive effort to articulate, and to build a society upon, an overarching truth. ${ }^{181}$ Later thinkers such as Montaigne may have harbored greater doubts about the scope of human understanding, as Toulmin argues, but they did not disavow the commitment to finding and living by as much truth as was attainable. So in trying to redirect life toward a greater conformity with truth, the classical Enlightenment was building on a commitment that was already in place.

By contrast, modern Enlightenment culture, as discussed above, is characterized by a self-conscious effort to distance at least public discourse from the larger questions of truth, or from the whole truth; and this effort is reinforced by post-modern squeamishness about the vocabulary and the very possibility of truth, and especially of Truth. In this setting, one can imagine a confrontation in which a revivified but disconcerted Descartes complains that the prevailing modern discourse in the public realm has lost its connection and commitment to truth. A Rawls might respond, "Excellent! That's what we've been working for," while a yawning Rorty might remark, "This sort of talk about 'truth' bores me. Can't we please discuss something else?"182

Prognosis is always hazardous, to be sure, but a renewed commitment to truth — in constitutional discourse, in public deliberation generally — does

180. Id. at 155

181. The very first chapter of the Summa Contra Gentiles asserts that "[t]ruth must consequently be the ultimate end of the whole universe, and the consideration of the wise man aims principally at truth." St. Thomas Aquinas, Summa Contra Gentiles 60 Bk. I, ch. 1 (Anton C. Pegis trans., 1975 ed.).

182. Asserting that "truth is not the sort of thing one should expect to have a philosophically interesting theory about," Rorty explains that when pragmatists like himself "suggest that we not ask questions about the nature of Truth and Goodness, they do not ... have a 'relativistic' or 'subjectivist' theory of Truth or Goodness. They would simply like to change the subject." RORTY, supra note 14, at xiii-xiv. 
not seem imminent. It appears that for the time being, we may have no alternative except to hunker down for what looks to be a long, dark night of Enlightenment. 